\title{
ODRŽIVA JAVNA NABAVA
}

Dr. sc. Marko Šikić, izvanredni profesor

Dr. sc. Marko Turudić, docent

Pravni fakultet Sveučilišta u Zagrebu
UDK: 35.073 .3

Ur.: 9. siječnja 2017.

Pr.: 22. veljače 2017.

Pregledni znanstveni rad

\begin{abstract}
Sažetak
U radu se analizira koncept održive javne nabave; teorijska podloga, razvoj implementacije u inozemne pravne sustave, pravo Europske unije i Republike Hrvatske. Nakon uvodnog postavljanja teorijskih okvira $i$ prepoznavanja potrebe za uvođenjem promicanja ciljeva održivog razvoja u javnonabavni pravni okvir, opisuje se razvoj koncepta u inozemnim pravnim sustavima. Nakon toga, prikazuje se postupni razvoj elemenata održivosti u javnoj nabavi u pravu Europske unije, kroz praksu Suda Europske unije i dva posljednja javnonabavna regulatorna okvira. U sljedećem dijelu rada analizira se sadašnji pravni sustav javne nabave u Republici Hrvatskoj radi utvrđivanja postojanja elemenata održivog razvoja, kao i praksa domaćih naručitelja u implementaciji elemenata održivosti u postupke javne nabave. Rad završava analizom kako će na domaći pravni sustav utjecati značajno širenje koncepta održive javne nabave u novom regulatornom okviru Europske unije.
\end{abstract}

Ključne riječi: upravno pravo, javna nabava, održivi razvoj, Europska unija.

\section{1. $U V O D$}

Pravo javne nabave važan je dio pravnog sustava svake države. Postupcima javne nabave država osigurava obavljanje gotovo svih svojih javnih funkcija, nabavljajući dobra, radove i usluge od važnosti za svoje djelovanje. Javnom nabavom koristi se značajan dio proračunskih sredstava države, čime ona predstavlja velik dio državne potrošnje, ali i značajan dio opće gospodarske djelatnosti u svakoj državi. Tako postoje procjene da javne nabave čine oko 19 posto BDP-a Europske unije ${ }^{1}$ (u nastavku rada: EU), dok je u Republici Hrvatskoj taj postupak nešto niži i čini oko 12 posto BDP-a. ${ }^{2}$ Upravo činjenica da država kroz postupke javne nabave čini

1 Izjava Povjerenika za unutarnje tržište i usluge Barniera povodom usvajanja novog regulatornog okvira za javnu nabavu, http://europa.eu/rapid/press-release_MEMO-14-18_en.htm?locale=en, pristupljeno 15. prosinca 2015.

2 Godine 2013. vrijednost javne nabave u Republici Hrvatskoj bila je 12,08 \% BDP-a, Statističko izvješće o javnoj nabavi u Republici Hrvatskoj za 2013. godinu Uprave za sustav javne nabave ministarstva gospodarstva, http://www.javnanabava.hr/userdocsimages/userfiles/file/ Statisti\%C4\%8Dka\%20izvje $\%$ C5\%A1\%C4\%87a/Godi\%C5\%A1nja/Statisticko_izvjesce_JN2013.pdf, str. 10. (15. prosinca 2015.). 
tako značajan dio gospodarstva, daje državi dodatnu moć i mogućnosti utjecaja na tržišna zbivanja. Kako su privatni poduzetnici vrlo zainteresirani za postupke javne nabave i mogućnosti koje pruža poslovanje s državom, državi se otvara mogućnost ostvarivanja i sekundarnih ciljeva, koji nikako nisu manje važni od primarnih ciljeva koji se ostvaruju postupcima javne nabave.

Ako kao primarne ciljeve odredimo učinkovito raspolaganje s javnim sredstvima, dobivanje najbolje moguće usluge, radova ili dobara uz najmanju moguću cijenu te zaštitu tržišnog natjecanja, kao sekundarne ciljeve možemo odrediti ostvarivanje određenih socijalnih i okolišnih ciljeva. ${ }^{3}$ Pod socijalnim ciljevima mislimo na ciljeve kao što su promicanje socijalno odgovornog poslovanja zapošljavanjem socijalno ugroženih i marginaliziranih skupina društva, poštovanje radničkih prava, dok bi okolišni ciljevi bili poticanje ekološki osviještenog poslovanja i korištenje proizvodnih i poslovnih procesa koji imaju minimalno štetan učinak na okoliš. Okvirni naziv za postupke javne nabave koji uvažavaju i ostvarenje takvih ciljeva je održiva javna nabava. Uvrštavanjem socijalnih i okolišnih kriterija kao uvjeta u postupcima javne nabave država može značajno poticati odgovorno poslovanje i unaprjeđivati dobrobit svojih građana, te ostvarivati ciljeve koji nisu nužno izravno vezani primarnim ciljevima javne nabave.

Takva razmišljanja u pravnoj teoriji i praksi javne nabave postoje već duže vrijeme. Praktične začetke održive javne nabave možemo pratiti od 19. stoljeća u Ujedinjenom Kraljevstvu (u nastavku rada: UK) i Sjedinjenim Američkim Državama (u nastavku rada: SAD). Tako je 1840. Predsjednik SAD-a Martin Van Buren izdao izvršnu naredbu kojom uspostavlja desetosatni radni dan za radnike koji rade na određenim državnim (javnonabavnim) ugovorima, dok je 1891. Parlament UK-a donio rezoluciju o pravičnim plaćama za radnike koji rade na državnim (javnonabavnim) ugovorima. ${ }^{4}$

U okviru prava EU-a održiva javna nabava javlja se u nekoliko javnonabavnih regulatornih okvira. Značajniji početci primjećuju se u regulatornom okviru iz 2004. ${ }^{5}$, dok snažan proboj dolazi tek u najnovijem regulatornom okviru iz 2014. godine. ${ }^{6}$ Ipak, koncept održive javne nabave ima i svoje nedostatke. Tako se u teoriji opravdano postavljaju pitanja koliko elementi održivosti u postupcima javne nabave utječu

3 Za sličnu podjelu vidi i Thai, K. V., Public procurement re-examined, Journal of public procurement, Volume 1, br. 1, 2001., str. 27.

4 McCrudden, C., Using public procurement to actieve social outcomes, Natural Resources Forum, vol. 28., br.4., 2004., str. 258.

5 Direktiva Europskog parlamenta i Vijeća 2004/18/EZ od 31. ožujka 2004. o usklađivanju postupaka za sklapanje ugovora o javnim radovima, ugovora o javnoj nabavi robe te ugovora o javnim uslugama i Direktiva Europskog parlamenta i Vijeća 2004/17/EZ od 31. ožujka 2004. o usklađivanju postupaka nabave subjekata koji djeluju u sektoru vodnog gospodarstva, energetskom i prometnom sektoru te sektoru poštanskih usluga.

6 Direktiva 2014/24/EU Europskog parlamenta i Vijeća od 26. veljače 2014. o javnoj nabavi i o stavljanju izvan snage Direktive 2004/18/EZ, Direktiva 2014/25/EU Europskog parlamenta i Vijeća od 26. veljače 2014. o nabavi subjekata koji djeluju u sektoru vodnog gospodarstva, energetskom i prometnom sektoru te sektoru poštanskih usluga i stavljanju izvan snage Direktive 2004/17/EZ, i Direktiva 2014/23/EU Europskog parlamenta i Vijeća od 26. veljače 2014. o dodjeli ugovora o koncesiji. 
na učinkovito trošenje proračunskih sredstava. Može se zaključiti i kako uvođenje elemenata održivosti kao uvjeta za ocjenu ponuda u postupcima javne nabave dodatno komplicira već ionako vrlo složen postupak i smanjuje transparentnost postupaka javnih nabava. Također, uspješnost ostvarivanja primarnih ciljeva javne nabave vrlo je lako empirijski utvrditi. Ali vrlo je teško učinkovito provjeriti koliko postupci održive javne nabave pozitivno utječu na ostvarenje upravo tih sekundarnih socijalnih i ekoloških ciljeva. Rad ćemo započeti definiranjem glavnih elemenata održive javne nabave i ciljeva koji se njome ostvaruju i povijesnim razvojem održive javne nabave u komparativnom pravu. U nastavku ćemo analizirati odredbe o održivoj javnoj nabavi iz javnonabavnih regulatornih okvira EU-a iz 2004. i 2014., te dostupnu praksu Suda Europske unije (u nastavku rada: CEU). Rad ćemo završiti analizom održive javne nabave u hrvatskom pravnom sustavu, usklađenosti s novim regulatornim okvirom EU-a i prijedlozima za unaprjeđenje.

\section{DEFINIRANJE ODRŽIVE JAVNE NABAVE}

Održiva javna nabava razvila se kroz praktične pokušaje uvođenja elemenata održivog razvoja u postupke javne nabave. Iako početci takvog razmišljanja postoje već čitavo stoljeće, o značajnom zamahu održivog razvoja u okviru javne nabave možemo govoriti tek u zadnjih tridesetak godina. Tako je nužno spomenuti važno Brundtland izvješće Svjetske komisije o okolišu i razvoju iz 1987., Konferenciju Ujedinjenih naroda o okolišu i razvoju iz 1992., koja je izazvala svjetske lidere da ponovno osmisle ekonomski razvoj na način da se spriječi uništavanje okoliša, ali i da se uzmu u obzir socijalni problemi. ${ }^{7}$

Održivu javnu nabavu može se definirati kao postupak u kojem ovlašteni naručitelji nabavljaju dobra, radove ili usluge pritom uzimajući u obzir: kriterije najbolje vrijednosti za novac kao cijena, kvaliteta, dostupnost, funkcionalnost, okolišne aspekte ("zelena javna nabava": učinci na okoliš koje proizvod ili usluga imaju tijekom postojanja ili pružanja), socijalni aspekti: učinci na iskorjenjivanje siromaštva, jednakost u distribuciji resursa, uvjeti rada i ljudska prava. ${ }^{8}$ Uzevši u obzir da primarni cilj svakog postupka javne nabave mora biti najbolja vrijednost za novac i racionalno trošenje proračunskih sredstava, ciljeve održivog razvoja možemo karakterizirati kao sekundarne ciljeve postupaka održive javne nabave. Ispunjenju tih sekundarnih ciljeva održiva javna nabava može doprinijeti izravno izvršenjem ugovora (kada ponuditelj smanji emisije ugljičnog dioksida vezane za proizvodnju ili dostavu proizvoda ili usluge ili ako zaposli pripadnike socijalno ugroženih skupina), ili neizravno, potičući gospodarske subjekte da promijene svoju poslovnu praksu u

7 Fisher, E., The Power of Purchase: Addressing Sustainability through Public Procurement, European procurement and public private partnership review, vol. 8., br. 1., 2013., str. 2.

8 McCrudden, C., Legal aspects of sustainable public procurement, https://www.google.hr/ url $? \mathrm{sa}=\mathrm{t} \& \mathrm{rct}=\mathrm{j} \& \mathrm{q}=\& \mathrm{esrc}=\mathrm{s} \&$ source $=$ web $\& \mathrm{~cd}=1 \& \mathrm{ved}=0 \mathrm{ahUKEwjF} 1 \mathrm{dih} 7 \mathrm{OLJ}$

AhXDEHIKHbADDzsQFggiMAA\&url=http $\% 3 \mathrm{~A} \% 2 \mathrm{~F} \% 2 \mathrm{Fmasterpublicprocuremen}$ t.itcilo.org\%2Fprivate-area\%2Flibrary\%2Fdocuments\%2Flegal-aspects-of-sustainab le-public-procurement $\% 2$ Fat_download\%2FAttachmentFile\&usg=AFQjCNHAiqBhg 2-JlvDXC-2KfR0uFZL-SQ\&sig2=CIF7h0xZSX68FAS2TiPx9A, (17. prosinca 2015.), str. 3. 
tom smislu. ${ }^{9}$

Kako načela održivog razvoja postaju sve važnija, pa tako i neizbježna odrednica ekonomskog razvoja zemalja, ona ne smiju biti upitna. Gospodarska moć države i njen sveobuhvatni utjecaj na tržište postupcima javne nabave dobra je podloga za ostvarivanje održivog razvoja. Implementiranjem načela održivog razvoja u kriterije za odabir najpovoljnije ponude posredno se utječe na usklađivanje poslovanja gospodarskih subjekata s načelima održivog razvoja. Ipak, implementiranje načela održivog razvoja u postupke javne nabave, pa makar i kao sekundarna načela, nailazi na kritike u teoriji i u praksi. Nekoliko je glavnih prigovora. Navodi se kako održiva javna nabava dodatno komplicira ionako složen postupak javne nabave, poskupljuje postupke javne nabave i otežava učinkovito trošenje proračunskih sredstava. ${ }^{10}$ Postoji i bojazan da održiva javna nabava dovodi do diferencijalnog tretmana domaćih i stranih ponuditelja u specifikacijama natječaja (npr. naglašavajući važnost recikliranog sadržaja u nabavi papira, a znajući da domaći proizvođači uglavnom papir proizvode recikliranjem, mogu se u nepovoljniji položaj dovesti inozemni ponuđači koji u proizvodnji papira koriste uglavnom nereciklirane sirovine). ${ }^{11}$ Naglasak na potvrdama o održivom poslovanju kao uvjetima pristupanja natječaju može imati diskriminatorni učinak na ponuditelje koji nemaju takve potvrde te oslanjanje na ekološke oznake za proizvode može imati isti učinak. ${ }^{12}$

\section{RAZVOJ ODRŽIVE JAVNE NABAVE U KOMPARATIVNOM PRAVU I PRAVU EU-A}

Početci uvođenja elemenata održivog razvoja u postupke javne nabave primjećuju se već krajem 19. stoljeća. U početku je naglasak bio isključivo na socijalnom aspektu koncepta održivosti. Tako u 19. stoljeću zamjećujemo početke vezivanja javne nabave i polako razvijajuće socijalne politike koja se očituje u brizi za nezaposlene i radnika općenito. U mnogo zemalja to je rezultiralo korištenjem javnih radova, nekad financiranih postupcima javne nabave, kao sredstva za borbu protiv nezaposlenosti. ${ }^{13} \mathrm{U}$ nekim zemljama javna nabava i javni ugovori korišteni su kako bi se propisala minimalna plaća. Tako je Davis-Bacon zakonom iz 1931. u SAD-u propisana minimalna plaća za radnike u projektima gradnje u kojima je SAD ili okrug Columbia bio stranka u ugovoru. ${ }^{14}$ Od 1960-ih do danas, svjedočimo ekspanziji antidiskriminacijskog prava pod utjecajem prava SAD-a. Tako se zaštita raznih društvenih manjina od diskriminacije počela provoditi i putem postupaka

9 Semple, A., The Link to the Subject-Matter: A Glass Ceiling for Sustainable Public Contracts?, $\mathrm{u}$ Sustainable public procurement under EU law: New perspectives on the state as stakeholder, Cambridge University Press, Cambridge, 2015., str. 2.

10 Conway, D. M., Sustainable Procurement Policies and Practices at the State and Local Government Level, Greening local government, K. Hirokawa \& P. Salkin, eds., 2012., https:// papers.ssrn.com/sol3/papers.cfm?abstract_id=2095576, pristupljeno 1. prosinca 2016., str. 48.

11 Ibid. str. 6.

12 Ibid.

13 McCruden, op. cit. (bilj. 4.), str. 258.

14 Ibid. 
javne nabave. ${ }^{15}$ To je posebice naglašeno u pravu SAD-a. Tako održivi elementi javne nabave u pravu SAD-a poglavito naglasak stavljaju na izbjegavanje diskriminacije i pružanje jednakih prilika svima u postupcima javne nabave. ${ }^{16}$ Takve su se ideje ostvarile kroz savezne propise koji su poticali sklapanje javnonabavnih ugovora $\mathrm{s}$ ponuditeljima čiji su vlasnici žene ili predstavnici manjina, s posebnim naglaskom na američke Indijance. ${ }^{17} \mathrm{U}$ skladu s time, vlada SAD-a, uspostavila je i pravne uvjete za nabavu od dobavljača u vlasništvu pripadnika manjina za kompanije koje žele sudjelovati u javnonabavnim postupcima, u čijem provođenju sudjeluje i posebna agencija, Agencija za razvoj poslovanja manjina (Minority Business Development Agency, MBDA). ${ }^{18}$

Navedene politike SAD je koristio i kao alat za zabranu nabave iz zemalja koje su tom trenutku imale, prema sudu SAD-a, socijalno neprihvatljivo ponašanje prema dijelu svoje vlastite populacije. Tako je SAD u vlastitim javnonabavnim postupcima isključivao ponuditelje iz Sjeverne Irske ili Južnoafričke Republike, kako bi lokalnim vlastima ukazao na neprihvatljivost religijske (Sjeverna Irska) ili rasne (Južnoafrička Republika) nesnošljivosti. ${ }^{19}$

Ideje održive javne nabave iz SAD-a proširile su se i na zemlje sa SAD-u pravno bliskim sustavima, kao što su Kanada, Australija i Novi Zeland. U Kanadi je, tako, 1986. usvojen Savezni program za ugovaratelje (Federal Contractors Programme), koji je propisao obvezu javnim naručiteljima na saveznoj i lokalnoj razini da u postupke javne nabave uključe obveze jednakog zapošljavanja. ${ }^{20}$ Nastavak takvog razvoja vidimo i u usvajanju Javnonabavne strategije za poduzeća u vlasništvu Aboridžina (Procurement strategy for Aboriginal Business) $)^{21}$ u Kanadi, kojom se potiče odabir ponuditelja u vlasništvu kanadskih Aboridžina u postupcima javne nabave. Također, postoji i čitav niz sličnih strategija na razini saveznih država. ${ }^{22}$

Australija i Novi Zeland donijeli su zajednički Vladin okvir za održivu javnu nabavu (Australian and New Zealand Government framework for Sustainable Procurement $)^{23}$, čiji je glavni cilj uspostaviti seriju nacionalnih načela koja bi pomogla

15 Ibid.

16 Brammer, S., Walker, H. L., Sustainable procurement practice in the public sector: An international comparative study, University of Bath Working Paper 2007, http://opus.bath. ac.uk/281/1/2007-16.pdf, pristupljeno 5. prosinca 2016., str. 12.

17 Ibid.

18 Worthington, I., Ram, M., Shah, M., Boyal, H., Drivers of and barriers to supplier diversity initiatives: a cross-national study, http://www.crrconference.org/Previous_conferences/ downloads/worthington.pdf, pristupljeno 5. prosinc 2016., str. 4. i 5.

19 Brammer, Walker, op. cit. (bilj. 16), str. 12.

20 Barraket, J., Keast, R., Furneaux, C., Social procurement and new public governance, Routlege, New York 2016., str. 35.

21 Procurement Strategy for Aboriginal Business, http://www.aadnc-aandc.gc.ca/eng/1100100032 802/1100100032803, pristupljeno 5. prosinca 2016.

22 Dragicevic, N., Ditta, S., Community benefits and social procurement policies - A jurisdictional review, https://mowatcentre.ca/wp-content/uploads/publications/121_community_benefits_ and_social_procurement_policies.pdf, pristupljeno 5. prosinca 2016., str. 7.

23 Australian and New Zealand Government Framework for Sustainable Procurement, http:// www.apcc.gov.au/ALLAPCC/APCC\%20PUB_ANZ\%20Government $\% 20$ Framework $\% 20$ for $\% 20$ Sustainable $\% 20$ Procurement $\% 20-\% 20$ Sept $\% 202007$.pdf, pristupljeno 5. prosinca 
javnim tijelima u implementiranju načela održivog razvoja u nabavu roba, usluga i radova. ${ }^{24}$

Nadležnost EU-a da regulira javnu nabavu proizlazi iz odredbi Ugovora o funkcioniranju Europske unije koje uređuju osnivanje i funkcioniranje unutarnjeg tržišta. Kao i u drugim područjima, svrhovito tumačenje relevantnih odredbi proširilo je doseg reguliranja izvan mjera nužno potrebnih za osiguranje slobodnog kretanja dobara, usluga, ljudi i kapitala. ${ }^{25}$ Arrowsmith i Kunzlik identificiraju tri načina na koje je javnonabavni regulatorni okvir EU razvijao unutarnje tržište: zabrana diskriminacije, osiguranje transparentnosti i uklanjanje nerazmjernih ograničenja pristupa tržištu. ${ }^{26}$

Održiva javna nabava u pravni poredak EU-a počela se probijati od 1980ih godina. Glavnu ulogu u implementiranju održivih načela u javnu nabavu imao je CEU, i tu primjećujemo određeni obrnuti pristup. Umjesto standardnog puta donošenja direktiva koje bi slijedila praksa CEU-a, u području održive javne nabave praksa CEU-a dovela je do implementacije načela održive javne nabave u kasnije direktive. U svojim odlukama, CEU je naglašavao kako glavni cilj EU prava o javnoj nabavi mora biti otvaranje javnih tržišta država članica konkurenciji i osiguravanje slobodnog kretanja dobara i usluga u cijeloj EU. Ipak, u nizu odluka CEU je naveo kako i drugi ciljevi mogu biti ostvarivani u postupcima javne nabave osim strogo ekonomskih, kao što su socijalni i okolišni. ${ }^{27}$ Najvažniji predmeti za uvođenje održive javne nabave u pravni predak EU-a su Bentjees ${ }^{28}$, Nord-Pas de Calais $^{29}$, Concordia ${ }^{30}$ i Wienstrom $^{31}$. U prva dva predmeta riječ je o ostvarivanju socijalnih ciljeva, dok je u druga dva predmeta riječ o ostvarivanju okolišnih ciljeva.

U predmetu Bentjees tužitelj je tvrdio da je odluka o odabiru u postupku javne nabave kojim je njegova ponuda odbijena, iako je bila najniža protivna tada važećoj Direktivi 70/305/EEC jer je naručitelj od ponuditelja tražio dokaz da će moći zaposliti dugoročno nezaposlene osobe. CEU je odlučio kako je navedeni uvjet u skladu s Direktivom pod uvjetom da nema izravni ili neizravni diskriminatorni učinak na ponuditelje iz drugih država članica, i da je takav uvjet spomenut u natječajnoj dokumentaciji. ${ }^{32}$

2016.

24 Australian and New Zealand Government Framework for Sustainable Procurement, http:// www.apcc.gov.au/ALLAPCC/APCC\%20PUB_ANZ\%20Government $\% 20$ Framework $\% 20$ for $\% 20$ Sustainable $\% 20$ Procurement $\% 20-\% 20$ Sept $\% 202007$.pdf, pristupljeno 5. prosinca 2016., str. 2.

25 Semple, A., Reform of the EU procurement Directives and WTO GPA: forward steps for sustainability?, http://papers.ssrn.com/sol3/papers.cfm?abstract_id=2089357, pristupljeno 20. prosinca 2016., str. 9.

26 Ibid.

27 Dragos, D. C., Neamtu, B., Sustainable public procurement in the EU: experiences and prospects, u Modernising public procurement: the new Directive, DJOF Publishing, Copenhhagen 2014., str. 302.

28 C-31/87 Gebroeders Bentjees BV protiv Nizozemske (1988) ECR 4635.

29 C-225/98 Komisija protiv Francuske (2000) ECR I-7445.

30 C-513/99 Concordia Bus (2002) ECR I-7213.

31 C-448/01 EVN $i$ Wienstrom (2003) ECR I-14527.

32 C-31/87 Gebroeders Bentjees BV protiv Nizozemske (1988) ECR 4635, točka 2. presude. 
Na navedeni predmet stranke su se pozivale i u predmetu Nord-Pas de Calais. U tom predmetu naručitelj je naveo promicanje zapošljavanja kao jedan od kriterija za dodjeljivanje ugovora. Europska komisija tumačila je Bentjees na način da se promicanje zapošljavanja može koristiti samo kao uvjet za ispunjenje upravnog ugovora o javnoj nabavi, a da kriteriji za odabir mogu biti samo najniža cijena ili ekonomski najpovoljnija ponuda. CEU se nije složio s takvim tumačenjem i naveo je kako naručitelj kao kriterij odabira ponuditelja može koristiti najnižu cijenu ili ekonomski najpovoljniju ponudu. Ukoliko se odluči za ekonomski najpovoljniju ponudu, može koristiti podkriterije kao cijenu, vremenski rok izvršenja, tekuće troškove, profitabilnost i tehničku stručnost. ${ }^{33}$ Kriterij promicanja zapošljavanja može se koristiti u takvom postupku javne nabave pod uvjetom da je u skladu s temeljnim načelima prava Zajednice, posebice načelima zabrane diskriminacije koje proizlazi iz odredbi Ugovora o funkcioniranju Europske unije o pravu slobodnog nastana i slobodi pružanja usluga. ${ }^{34}$ Nadalje, iako je taj kriterij u skladu s Direktivom 93/37, CEU zaključuje kako se mora primjenjivati u skladu sa svim postupovnim pravilima koja određuje ta direktiva, osobito s pravilima o oglašavanju, što znači da kriterij poticanja zapošljavanja mora biti izričito spomenut u obavijesti o tom konkretnom javnonabavnom natječaju. ${ }^{35}$

U predmetu Concordia grad Helsinki raspisao je natječaj za usluge autobusnog prijevoza. Kao glavni kriterij izabrao je ekonomski najpovoljniju ponudu, i u sklopu toga se oslanjao na tri podkriterija: cijenu, kvalitetu autobusa i kvalitetu i ekološko djelovanje ponuditelja. Sukladno drugom podkriteriju preferirani su autobusi s manjim štetnim emisijama i bukom, a sukladno trećem podkriteriju dodatne bodove dobivali su ponuditelji koji su imali certificiran program zaštite okoliša. ${ }^{36}$ Ponuditelj Concordia Bus nije dobio ugovor iako je ponudio najnižu cijenu, te su pred sudom tvrdili da je drugi podkriterij bio diskriminatoran. CEU u presudi ponavlja neke od uvjeta već izrečenih u Nord-Pas de Calais presudi, kao što su nužnost suglasnosti sa postupovnim pravilima Direktive 93/37 (u smislu oglašavanja), kao i usklađenosti s temeljnim načelima prava Zajednice. ${ }^{37}$ Također, CEU navodi da ako naručitelj odluči dodijeliti javnonabavni ugovor ponuditelju koji podnese ekonomski najpovoljniju ponudu, može uzeti u obzir kriterije koji se odnose na zaštitu okoliša. Takvi uvjeti moraju biti povezani s predmetom ugovora, ne smiju davati naručitelju neograničenu slobodu izbora ponuditelja, moraju biti izričito spomenuti u dokumentaciji za nadmetanje i obavijesti o natječaju te moraju biti u skladu s temeljnim načelima prava Zajednice, ponajprije načelom zabrane diskriminacije. ${ }^{38}$ Dalje, potrebno je bilo utvrditi jesu li ekološki kriteriji u konkretnom slučaju direktno vezani za predmet ugovora i daju li naručitelju neograničenu slobodu izbora ponuditelja. CEU smatra kako se kriteriji povezani s razinom dušikova oksida i razine buke autobusa, koje je naručitelj naveo, moraju smatrati izravno povezanim s predmetom ugovora, koji se odnosio

33 C-225/98 Komisija protiv Francuske (2000) ECR I-7445., paragraf 49.

34 C-225/98 Komisija protiv Francuske (2000) ECR I-7445., paragraf 50.

35 C-225/98 Komisija protiv Francuske (2000) ECR I-7445., paragraf 51.

36 C-513/99 Concordia Bus (2002) ECR I-7213., paragraf 21 i 22.

37 C-513/99 Concordia Bus (2002) ECR I-7213., paragraf 62 i 63.

38 C-513/99 Concordia Bus (2002) ECR I-7213., paragraf 64. 
na nabavu autobusa za javni prijevoz. ${ }^{39}$ Također, CEU je zaključio kako kriterij u kojem se dodatni bodovi dodjeljuju ponuditeljima koji zadovolje određene specifične i objektivno odredive okolišne kriterije nisu takvi da daju naručitelju neograničenu slobodu izbora ponuditelja. ${ }^{40}$

U predmetu Wiestrom, dokumentacijom za nadmetanje zahtijeva se od ponuditelja da energiju nabavljaju iz obnovljivih izvora. Kako bi se kvalificirali, ponuditelji moraju dokazati kako mogu pružiti energije iz obnovljivih izvora minimalno u iznosu procijenjene godišnje potrošnje ureda državnih tijela Republike Austrije, te je uveden i kriterij za dodjelu koji je činio $45 \%$ ocjene, a kojim su se dodjeljivali dodatni bodovi za energiju iz obnovljivih izvora iznad propisanog minimuma ${ }^{41} \mathrm{CEU}$ je odlučio kako je dopustivo da naručitelj, ako se odlučio za ekonomski najpovoljniju ponudu kao kriterij, koristi kriterij energije proizvedene iz obnovljivih izvora energije. Taj kriterij, kao i u prethodno prikazanim presudama, mora biti povezan s predmetom ugovora, ne smije davati naručitelju neograničenu slobodu izbora ponuditelja, mora biti izričito spomenut u dokumentaciji za nadmetanje i obavijesti o natječaju te mora biti u skladu $\mathrm{s}$ temeljnim načelima prava Zajednice, posebice načelom zabrane diskriminacije. ${ }^{42}$ Također, CEU navodi kako je dopustivo koristiti uvjet od $45 \%$ energije iz obnovljivih izvora energije kao kriterije odabira, iako oni ne predstavljaju izravnu ekonomsku korist za naručitelja i može im se dati značajna važnost i postupku odabira ponuditelja. ${ }^{43}$ Ipak, nije dopustivo koristiti takav kriterija ako ga ne prate uvjeti koji omogućavaju provjeru točnosti takvih podataka u ponudama, i ako se od ponuditelja zahtijeva da navedu koliko električne energije mogu isporučiti iz obnovljivih izvora energije neodređenoj skupini potrošača, i dodjeljuje maksimalni broj bodova ponuditelju koji navede najviši iznos, i gdje se količina isporuke uzima u obzir samo toliko da premašuje količinu potrošnje koja se očekuje u kontekstu predmeta nabave. ${ }^{44}$

Navedena praksa CEU-a poslužila je kao podloga u donošenju javnonabavnog regulatornog okvira EU-a iz 2004., u kojem se usvajaju elementi održive javne nabave. Takvi se elementi primjećuju i u drugim propisima. Tako je Direktivom 2009/33/ $\mathrm{EC}^{45}$ propisano kako naručitelji kod nabave vozila moraju uzimati u obzir njihovu potrošnju i štetne emisije, dok je Energy Star uredbom ${ }^{46}$ propisano kako državna tijela moraju kupovati samo onu informatičku opremu koja zadovoljava minimum energetske učinkovitosti.

39 C-513/99 Concordia Bus (2002) ECR I-7213., paragraf 65.

40 C-513/99 Concordia Bus (2002) ECR I-7213., paragraph 66.

41 C-448/01 EVN $i$ Wienstrom (2003) ECR I-14527., paragraf 18.

42 C-448/01 EVN $i$ Wienstrom (2003) ECR I-14527., paragraf 34.

43 C-448/01 EVN $i$ Wienstrom (2003) ECR I-14527., paragraf 72.

44 C-448/01 EVN $i$ Wienstrom (2003) ECR I-14527., paragraf 72.

45 Direktiva 2009/33/EC Europskog parlamenta i Vijeća od 23. travnja 2009. o poticanju čistih i energetski učinkovitih cestovnih vozila.

46 Uredba (EC) br. 106/2008 o zajedničkom programu oznaka o energetskoj učinkovitosti za uredsku opremuI ONDA LEGAL ORDER EU IZ PRIRUČNIKAetnog sustava praćenja, jako je teško precizno utvrditi učinak navedenih postupaka.nu inkluzi 


\section{REGULATORNI OKVIR IZ 2004. GODINE}

Javnonabavnim regulatornim okvirom EU-a iz 2004. načela održive javne nabave po prvi put dolaze u direktive. Navedeni regulatorni okvir čine direktive 2004/18/EZ ${ }^{47}$ i 2004/17/EZ ${ }^{48}$. Kako se Direktivom 2004/17/EZ uređuju javnonabavne specifičnosti kada je naručitelj iz specifičnih sektora vodoopskrbe, energije, transporta i poštanskih usluga, načela održive javne nabave prezentirat ćemo iz opće Direktive 2004/18/EZ. Također, Direktiva 2004/17/EZ ima praktički identične odredbe o održivoj javnoj nabavi kao i opća Direktiva 2004/18/EZ. Bitno je naglasiti kako su te direktive, u smislu održive javne nabave, imale vrlo ograničen doseg. Neposredno s njima, razvijao se čitav sustav sekundarnog prava EU-a čije su mjere u određenom obliku nametale nabavu s okolišnim elementima i (u manjoj mjeri) sa socijalnim elementima. ${ }^{49}$

U uvodnim odredbama Direktive 2004/18/EZ navodi se kako se temelji na sudskoj praksi CEU-a, posebno sudskoj praksi koja se odnosi na kriterije dodjele, koja pojašnjava mogućnosti da javni naručitelji udovolje potrebama javnosti koja je u pitanju, uključujući i ekološko i/ili socijalno područje pod uvjetom da su takvi kriteriji povezani sa sadržajem ugovora, ne daju neograničenu slobodu izbora javnim naručiteljima, izričito su spomenuti i zadovoljavaju temeljna načela. ${ }^{50}$ Navedenim paragrafom potvrđuje se važnost prakse CEU-a za donošenje ove Direktive, i potvrđuje se kako su rješenja iz prakse CEU-a izravno u njoj uobličena. Dalje, zahtjevi za zaštitom okoliša moraju se integrirati u definiciju i provedbu politike i aktivnosti EU-a, posebno radi promicanja održivog razvoja. Ova Direktiva, prema tomu, pojašnjava kako javni naručitelji mogu doprinijeti zaštiti okoliša i promicanju održivog razvoja, ujedno osiguravajući mogućnost dobivanja najbolje vrijednosti za novac za svoje ugovore. ${ }^{51}$ Također, ništa u ovoj Direktivi ne bi trebalo spriječiti nametanje ili provedbu mjera nužnih za zaštitu javne politike, javnog morala, javne sigurnosti, zdravlja, ljudskog života i životinjskog svijeta ili očuvanje biljnog svijeta, posebno kako bi se osigurao održivi razvoj, pod uvjetom da su te mjere u skladu s Ugovorom. ${ }^{52}$ Ovim odredbama Direktive uspostavljaju se načela zaštite okoliša i održivog razvoja kao sekundarna načela koja se ostvaruju u postupku javne nabave, budući da se navodi kako se

47 Direktiva Europskog parlamenta i VijećaI ONDA LEGAL ORDER EU IZ PRIRUČNIKAetnog sustava praćenja, jako je teško precizno utvrditi učinak navedenih postupaka.nu inkluzi 2004/18/ EZ od 31. ožujka 2004. o usklađivanju postupaka za sklapanje ugovora o javnim radovima, ugovora o javnoj nabavi robe te ugovora o javnim uslugama.

48 Direktiva Europskog parlamenta i VijećaI ONDA LEGAL ORDER EU IZ PRIRUČNIKAetnog sustava praćenja, jako je teško precizno utvrditi učinak navedenih postupaka.nu inkluzi 2004/17/EZ od 31. ožujka 2004. o usklađivanju postupaka nabave subjekata koji djeluju u sektoru vodnog gospodarstva, energetskom i prometnom sektoru te sektoru poštanskih usluga.I ONDA LEGAL ORDER EU IZ PRIRUČNIKAetnog sustava praćenja, jako je teško precizno utvrditi učinak navedenih postupaka.nu inkluzi

49 Caranta, R., Sustainable public procurement in the EU, The law of green and sustainable procurement in Europe, DJOF Publishing, 2010., str. 18.

50 Paragraf 1. Direktive 2004/18/EZ.

51 Paragraf 5. Direktive 2004/18/EZ.

52 Paragraf 6. Direktive 2004/18/EZ. 
ujedno mora osigurati dobivanje najbolje vrijednosti za novac. Također, naglašava se kako odredbe Direktive ne smije sprječavati ostvarivanje socijalnih i ekoloških ciljeva. Paragrafom 33. propisano je kako su uvjeti izvršenja ugovora sukladni s ovom Direktivom pod uvjetom da nisu izravno ili neizravno diskriminirajući i da su navedeni u pozivu na nadmetanje ili u ugovornim dokumentima. Oni mogu posebno biti namijenjeni da daju prednost strukovnoj izobrazbi na radnom mjestu, zapošljavanju ljudi koji imaju osobitih teškoća u postizanju integracije, borbi protiv nezaposlenosti ili zaštiti okoliša. Socijalni i okolišni ciljevi tako mogu biti dio uvjeta izvršenja ugovora o javnoj nabavi ako nisu diskriminirajući i ako su pravovremeno objavljeni.

Jedan od bitnih socijalnih elemenata Direktive 2004/18/EZ su i rezervirani ugovori. Tako se državama članicama daje mogućnost rezerviranja prava na sudjelovanje u postupcima nabave zaštitnim radionicama ili omogućavanja da se takvi ugovori izvršavaju u kontekstu zaštićenih programa zapošljavanja ako je većina zaposlenih osobe s invaliditetom koje zbog prirode ozbiljnosti svojeg invaliditeta ne mogu obavljati zanimanja u redovitim uvjetima. ${ }^{53}$

U člancima Direktive 2004/18/EZ održiva javna nabava spominje se i u okviru propisivanja tehničkih specifikacija. Tako se navodi da kada javni naručitelj utvrdi karakteristike koje se odnose na okoliš u obliku izvedbenih ili funkcionalnih zahtjeva može se služiti detaljnim specifikacijama, ili, ako je potrebno, njihovim dijelovima, kako je definirano europskim ili (više)nacionalnim ekološkim oznakama ili bilo kojom drugom ekološkom oznakom, pod određenim uvjetima. ${ }^{54}$

Također, javni naručitelji mogu odrediti posebne uvjete vezane za izvršenje ugovora, pod uvjetom da su oni sukladni s pravom Zajednice i da su navedeni u pozivu na nadmetanje ili u specifikacijama. Uvjeti kojima se uređuje izvršenje ugovora mogu se, posebno, odnositi na socijalne i okolišne aspekte. ${ }^{55}$ Navedeni uvjeti moraju biti usko vezani za predmet javnonabavnog natječaja. Stoga, ako javni naručitelj želi da u izvršenju ugovora sudjeluju pripadnici ugroženih manjina ili da se pri izvršavanju ugovora zadrže radnici starije dobi, takav zahtjev mora biti povezan s predmetom nabave. ${ }^{56}$

Javni naručitelj može navesti u ugovornim dokumentima, ili država članica može od njega tražiti da navede, tijelo ili tijela od kojih natjecatelj ili ponuditelj može dobiti odgovarajuću informaciju o obvezama vezanim uz poreze, zaštitu okoliša, odredbe o zaštiti radnog mjesta i radne uvjete koje su na snazi u državi članici, regiji ili mjestu u kojemu će se izvoditi radovi ili pružati usluge i koje će biti primjenjive na radove koji se izvode na gradilištu ili na usluge koje se pružaju tijekom izvršenja ugovora. ${ }^{57}$

53 Članak 19. Direktive 2004/18/EZ.

54 "Da su te specifikacije prikladne za definiranje značajki robe ili usluga koje su predmet ugovora, da su zahtjevi za oznaku sastavljeni na temelju znanstvenih podataka, da su ekološke oznake donesene u postupku u kojem mogu sudjelovati sve zainteresirane strane kao što su državna tijela, potrošači, proizvođači, distributeri i organizacije za zaštitu okoliša, i da su dostupne svim zainteresiranim stranama", članak 23. stavak 6. Direktive 2004/18/EZ.

55 Članak 26. Direktive 2004/18/EZ.

56 Poulsen, S. T., Jakobsen, P. S., Kalsmose-Hjelmborg S. E., EU public procurement law, DJOF Publishing, 2012., str. 309.

57 Članak 27. Direktive 2004/18/EZ. 
Ako javni naručitelji zahtijevaju prilaganje potvrda o sukladnosti gospodarskog subjekta s određenim normama za upravljanje okolišem koje izdaju neovisna tijela za potvrđivanje sukladnosti, moraju uputiti na Sustav Zajednice za upravljanje okolišem (EMAS) ili na norme upravljanja okolišem utemeljene na relevantnim europskim ili međunarodnim normama koje su potvrdila tijela koja udovoljavaju pravu Zajednice ili relevantnim europskim ili međunarodnim normama koje se odnose na potvrđivanje..$^{58}$ Moraju priznati jednakovrijedne potvrde tijela osnovanih u drugim državama članicama. Također moraju prihvatiti druge dokaze koji potvrđuju da gospodarski subjekt primjenjuje jednakovrijedne mjere upravljanja okolišem. ${ }^{59}$

Direktiva razlikuje ekonomski najpovoljniju ponudu i najnižu cijenu kao dvije glavne vrste kriterija za odabir ponude. Ako naručitelj odabere ekonomski najpovoljniju ponudu kao kriterij za odabir ponude, tada kao jedan od podkriterija može odabrati i ekološke osobine radova, dobara ili usluga. ${ }^{60}$ Sukladno navedenome, ako se naručitelj odluči za kriterij najniže cijene, tada se u postupku odabira ne može uzeti u obzir nijedan kriterij osim finalne cijene dobara, radova ili usluga. Ekonomski najpovoljnija ponuda predstavlja "najbolju vrijednost za novac", što se tumači tako da se podupire ostvarenje okolišnih ciljeva. Države članice ne moraju dodjeljivati javnonabavne ugovore na temelju najniže cijene, već mogu ugovore dodjeljivati i na temelju ekonomski najpovoljnije ponude, koja dopušta korištenje širih kriterija, koji nužno nemaju direktne veze s cijenom, kao što su okolišni ciljevi. ${ }^{61}$ To potvrđuje stajalište iz prijašnjih presuda CEU-a gdje je zaključeno kako termin "ekonomski korisno" može obuhvaćati i neekonomske faktore kao što je održivi razvoj. ${ }^{62}$ Bitno je napomenuti kako navedeni članak kao podkriterij ne navodi socijalne osobine, što bitno smanjuje mogućnost vođenja održivih postupaka javne nabave. Također, strogo inzistiranje na povezanosti sa predmetom nabave značajno smanjuje mogućnost ostvarenja socijalnih ciljeva nasuprot ostvarenju okolišnih ciljeva. ${ }^{63}$ Važno je i napomenuti kako naručitelji, sukladno javnonabavnom regulatornom okviru EU-a iz 2004., nisu obvezni implementirati elemente održivosti u postupke javne nabave. Uvođenje održivih elemenata ostavljeno je samo kao mogućnost o kojoj će naručitelji diskrecijski odlučivati od slučaja do slučaja, što je zasigurno doprinijelo rijetkom korištenju elemenata održivosti u većini država članica EU-a, pa tako i u Republici Hrvatskoj.

58 Članak 50. Direktive 2004/18/EZ.

59 Članak 50. Direktive 2004/18/EZ.

60 Članak 53. stavak 1. točka a) Direktive 2004/18/EZ.

61 Ganley, S. D., "Green product" procurement polici in the European union: treatment of life cycle carbon analysis and enviromental ppn restrictions, https://www.google.hr/ url? $\mathrm{sa}=\mathrm{t} \& \mathrm{rct}=\mathrm{j} \& \mathrm{q}=\& \mathrm{esrc}=\mathrm{s} \&$ source $=$ web\& $\mathrm{cd}=1 \& \mathrm{ved}=0 \mathrm{ahUKEwjbh} 8$ jlInMAhUDkywKHU 4oA8cQFggdMAA\&url=https $\% 3 \mathrm{~A} \% 2 \mathrm{~F} \% 2 \mathrm{Facademiccommons.columbia.edu} \% 2 \mathrm{Fdownload}$ $\% 2$ Ffedora_content $\% 2$ Fdownload\%2Fac\%3A187221\%2FCONTENT\%2Fganley_eu_ product_procurement.pdf\&usg=AFQjCNF7yUe7D74YNReQIdjok80ptoBjyg\&sig2=vVcf6aP PHESINQYEQzDXg, pristupljeno 20. prosinca 2016., str. 3.

62 Ibid.

63 Burgi, M., Brandmeier, B., Quality as an Interacting Award Criterion under Current and Future EU-Law, European procurement and public partnership law review, vol. 9., br. 1., 2014., str. 15. 


\section{NOVI REGULATORNI OKVIR}

Novi javnonabavni okvir EU-a čine tri direktive. Direktiva 2014/24/EU ${ }^{64}$ je opća javnonabavna direktiva, dok se Direktivom 2014/25/EU ${ }^{65}$ uređuje nabava sektorskih naručitelja. Direktivom 2014/23/EU ${ }^{66}$ prvi puta se zasebno uređuje materija koncesija. Jedan od glavnih ciljeva novog regulatornog okvira omogućavanje je veće razine strateškog korištenja javne nabave, posebice u vidu ostvarivanja okolišnih, socijalnih i ekonomskih ciljeva. Mogućnosti naručitelja da ostvaruju održive ciljeve u postupcima javne nabave oprezno su balansirane s obzirom na imperative učinkovitog tržišnog natjecanja i transparentnosti. ${ }^{67}$ Reforma javne nabave u okviru EU sadrži nekoliko suprotstavljenih ciljeva: jačanje unutarnjeg tržišta, želja za korištenjem javne nabave kako bi se ostvarili određeni politički ciljevi, želja za održanjem već poznatog postupka i imperativ ispunjavanja obveza iz međunarodnih ugovora kao što je WTO sporazum o državnoj nabavi (u nastavku rada: GPA). ${ }^{68}$ GPA je najvažniji međunarodni pravni instrument za javnu nabavu. Kako je EU stranka potpisnica, obvezna je svim odredbama sporazuma, $\mathrm{i}$ ta je činjenica morala biti uzeta u obzir kod sastavljanje $i$ javnonabavnog regulatornog okvira iz 2004., ali i najnovijega iz 2014., jer su izmjene GPA stupile na snagu 2012. godine.

GPA navodi općenita načela zabrane diskriminacije i transparentnosti i propisuje posebna pravila za tehničke specifikacije, izbor ponuditelja i procjenu ponuda. ${ }^{69}$ Što se tiče održive javne nabave, sadrži odredbe o mogućnosti uključivanja okolišnih elemenata u tehničke specifikacije i kriterije za odabir. Nažalost, GPA se ne očituje o socijalnim aspektima, što ipak ne znači da ih je nemoguće uvrstiti ako zadovoljavaju uvjete proizašle iz općih načela GPA. ${ }^{70}$

Vjerojatno najvažnije novine (u nizu novina koje se tiču održive javne nabave) novog regulatornog okvira koje podržavaju održivu javnu nabavu su odredbe koje se odnose na tehničke specifikacije, kriterije odabira ponude, uvjete za izvršenje ugovora, troškove životnog vijeka i ekološke oznake. Navedenim novinama ćemo i posvetiti najviše pažnje u nastavku rada. Koncentrirat ćemo se na Direktivu 2014/24/ EU, kao najvažniju i opću javnonabavnu direktivu.

\subsection{Tehničke specifikacije}

Tehničke specifikacije uređuju se člankom 42. Direktive 2014/24/EU. Navedenim člankom propisano je kako se tehničkim specifikacijama utvrđuju značajke

64 Direktiva 2014/24/EU Europskog parlamenta i Vijeća od 26. veljače 2014. o javnoj nabavi i o stavljanju izvan snage Direktive 2004/18/EZ.

65 Direktiva 2014/25/EU Europskog parlamenta i Vijeća od 26. veljače 2014. o nabavi subjekata koji djeluju u sektoru vodnog gospodarstva, energetskom i prometnom sektoru te sektoru poštanskih usluga i stavljanju izvan snage Direktive 2004/17/EZ.

66 Direktiva 2014/23/EU Europskog parlamenta i Vijeća od 26. veljače 2014. o dodjeli ugovora o koncesiji.

67 Semple, op. cit. (bilj. 9.), str. 4.

68 Ibid.

69 Dragos, Neamtu, op. cit. (bilj. 27.), str. 10.

70 Ibid., str. 11. 
koje se traže za radove, usluge ili robu koji su predmet postupka javne nabave. One se mogu odnositi i na određen proces ili metodu proizvodnje ili izvedbe zatraženih radova, nabave robe ili pružanja usluga ili na određeni proces neke druge faze njihova životnog vijeka čak i ako ti čimbenici nisu sastavni dio njihova materijalnog sadržaja pod uvjetom da su povezani s predmetom ugovora i razmjerni njegovoj vrijednosti i ciljevima. ${ }^{71}$ Također, ne dovodeći u pitanje obvezna nacionalna tehnička pravila, $u$ onoj mjeri u kojoj su usklađena s pravom Unije, tehničke se specifikacije formuliraju (između ostalog): u smislu izvedbenih ili funkcionalnih zahtjeva, uključujući okolišne značajke, pod uvjetom da su ti parametri dovoljno precizni kako bi ponuditelji mogli odrediti predmet ugovora, a javnim naručiteljima omogućiti dodjelu ugovora. ${ }^{72}$ Navedenim člankom određeno je kako se značajke koje se odnose na predmet nabave mogu odnositi i na način proizvodnje ili izvedbe predmeta nabave neovisno o fazi životnog vijeka proizvoda te se izričito navode okolišne značajke predmeta javne nabave kao element tehničkih značajki predmeta javne nabave.

\subsection{Kriteriji za odabir ponude, isključenje ponuditelja}

Kriteriji za odabir ponude određeni su člankom 67. Direktive 2014/24/EU. Naručitelji temelje dodjelu ugovora o javnoj nabavi na ekonomski najpovoljnijoj ponudi. Ekonomski najpovoljnija ponuda sa stajališta javnog naručitelja utvrđuje se na temelju cijene ili troška, primjenom pristupa isplativosti, kao što je trošak životnog vijeka te može uključivati najbolji omjer između cijene i kvalitete, koji se ocjenjuje na temelju kriterija. Ti kriteriji uključuju kvalitativne, okolišne i/ili socijalne aspekte, povezane $\mathrm{s}$ predmetom dotičnog javnog ugovora. Ti kriteriji mogu obuhvaćati, između ostalog i socijalne i okolišne značajke. ${ }^{73}$ Ključan uvjet za pravilnu primjenu kriterija za odabir ponude je da korišteni kriteriji imaju vezu s predmetom postupka javne nabave. Tako se smatra da su kriteriji za odabir ponude povezani s predmetom javnog ugovora ako se odnose na radove, robu ili usluge koje se pružaju u okviru tog ugovora u bilo kojem aspektu i u bilo kojoj fazi njihova životnog vijeka, uključujući čimbenike obuhvaćene u: određenom postupku proizvodnje, nabave ili trgovine tim radovima, robom ili usluga; ili određenom postupku za drugu fazu njihova životnog vijeka i onda kada takvi čimbenici nisu dio njihova materijalnog sadržaja. ${ }^{74}$

Potreba povezanosti kriterija odabira i predmeta postupka javne nabave $u$ Direktivu je implementirana iz Concordia predmeta CEU-a. Okolišne kriterije za odabir ponude tako mogu činiti eksternalije povezane s potrošnjom (emisije ugljičnog dioksida), eksternalije povezane s proizvodnjom (korištenje obnovljivih izvora energije kod proizvodnje), trošak životnog vijeka (korištenje, održavanje, troškovi i učinak otpisa). ${ }^{75}$

Vezano uz socijalne kriterije, iako je prije bilo sumnji u zakonitost njihova korištenja jer su uglavnom vezani za ponašanje ponuditelja, a ne za sam predmet

71 Članak 42. točka 1. Direktive 2014/24/EU.

72 Članak 42. točka 3. Direktive 2014/24/EU.

73 Članak 67. stavak 2. Direktive 2014/24/EU.

74 Članak 67. stavak 3. Direktive 2014/24/EU.

75 Dragos, Neamtu, op. cit. (bilj. 27.), str. 13. 
postupka javne nabave, CEU je u predmetu Max Havelaar $^{76}$ razjasnio kako socijalni kriteriji kao Fair Trade proizvodnja mogu biti primijenjeni pod određenim uvjetima. U navedenom predmetu Kraljevina Nizozemska je u postupku javne nabave automatskih aparata za kavu u tehničkim specifikacijama navela nužnost posjedovanja EKO i Max Havelaar oznaka za ponuditelje. ${ }^{77}$ Ovdje je posebno zanimljiva oznaka Max Havelaar ${ }^{78}$, koja se odnosi na proizvode sa Fairtrade karakteristikama, kao što su proizvodi proizvođača koji isplaćuju svojim zaposlenicima plaće redovito, omogućavaju im osnivanje sindikata, zdravstveno osiguranje i slično. ${ }^{79} \mathrm{U}$ navedenom predmetu Komisija je, između ostalog, tvrdila kako je Kraljevina Nizozemska, propisavši navedene oznake kao uvjet, prekršila članak 53. Direktive 2004/18, budući da ti uvjeti nisu vezani s predmetom ugovora, jer se oznake EKO i Max Havelaar odnose na proces proizvodnje, a ne na sam proizvod te da su takvi uvjeti ujedno i diskriminatorni i netransparentni. ${ }^{80} \mathrm{CEU}$ zaključuje, referirajući se na prije prikazanu Wienstrom presudu, kako je moguće da naručitelj navede uvjete koji su vezani za način proizvodnje, a ne i na sam proizvod ${ }^{81}$ Ipak, da bi se takav uvjet mogao koristiti, potrebno je odrediti kriterije koje te oznake moraju zadovoljiti, kao i mehanizme kojima se može dokazati da određeni proizvod, odnosno metoda njegove proizvodnje zadovoljava navedene uvjete. ${ }^{82}$

U sklopu ovog poglavlja osvrnut ćemo se i na mogućnosti korištenja elemenata održive javne nabave za isključenje određenih ponuditelja iz postupka javne nabave. Tako je člankom 20. Direktive 2014/24/EU ostavljena mogućnost državama članicama da rezerviraju pravo sudjelovanja u postupcima javne nabave zaštićenim radionicama i gospodarskim subjektima čiji je osnovni cilj društvena i profesionalna integracija osoba s invaliditetom ili osoba u nepovoljnom položaju ili mogu za takve ugovore omogućiti izvršenje u kontekstu programa zaštićenih zaposlenja, ako najmanje 30 $\%$ zaposlenih osoba u tim radionicama, gospodarskim subjektima ili programima predstavljaju radnici koji su osobe s invaliditetom ili radnici u nepovoljnom položaju.

Ovim je člankom izmijenjen članak 19. Direktive 2004/18/EC tako da je dodan uvjet od 30\% zaposlenih osoba s invaliditetom ili u nepovoljnijem položaju. Također, ponuditelj može biti isključen iz postupka javne nabave ako javni naručitelj dozna da gospodarski subjekt ne poštuje svoje obveze koje se odnose na plaćanje poreza ili doprinosa za socijalno osiguranje $i$ ako je to utvrđeno obvezujućom sudskom ili upravnom odlukom u skladu s pravnim odredbama države u kojoj ima sjedište, ili s državama članicama javnog naručitelja, ili ako to može dokazati sam naručitelj. ${ }^{83}$ Zanimljivo je da države članice mogu predvidjeti odstupanje od obvezujućeg isključenja ponuditelja, čak i ako krši navedene socijalne obveze, zbog bitnih zahtjeva

76 C-368/10, Komisija protiv Nizozemske (2012).

77 C-368/10, Komisija protiv Nizozemske (2012), paragraf 1.

78 Max Havelaar web stranica, http://maxhavelaar.nl/english, pristupljeno 2. prosinca 2016.

79 Fairtrade web stranica, http:/www.fairtrade.net/about-fairtrade/what-is-fairtrade.html, pristupljeno 2. prosince 2016.

80 C-368/10, Komisija protiv Nizozemske (2012), paragraf 82.

81 C-368/10, Komisija protiv Nizozemske (2012), paragraf 91.

82 C-368/10, Komisija protiv Nizozemske (2012), paragraf 97.

83 Članak 57. stavak 2. Direktive 2014/24/EU. 
koji se odnose na javni interes kao što je javno zdravlje ili zaštita okoliša ${ }^{84}$ Primjer za takvo postupanje država članica bila bi situacija u kojoj je nužno hitno nabaviti cjepiva koja proizvodi jedino ponuditelj kod kojeg postoji neki od gore navedenih razloga za isključenje iz postupka javne nabave..$^{85}$

Dodatno, važno je napomenuti kako države članice moraju poduzimati odgovarajuće mjere kako bi osigurale da u provođenju javnih ugovora gospodarski subjekti udovoljavaju primjenjivim obvezama u području prava okoliša, socijalnog i radnog prava određenog pravom EU-a, nacionalnim pravom, kolektivnim ugovorima ili odredbama međunarodnog prava okoliša, socijalnog i radnog prava, te da naručitelji mogu isključiti ili mogu zatražiti od država članica da isključe iz sudjelovanja u postupku nabave bilo koji gospodarski subjekt koji krši navedene obveze. ${ }^{86}$

\subsection{Uvjeti za izvršenje ugovora}

U članku 70. Direktiva 2014/24/EU predviđa mogućnost korištenja održivih uvjeta u uvjetima za izvršenje ugovora. Tako javni naručitelji mogu odrediti posebne uvjete vezane za izvršenje ugovora, pod uvjetom da su oni povezani s predmetom ugovora i navedeni u pozivu na nadmetanje ili dokumentaciji o nabavi. Oni mogu uključivati gospodarske, okolišne, društvene aspekte ili one povezane s inovacijama i zaposlenošću. ${ }^{87}$ Glavna razlika između održivih elemenata u tehničkim specifikacijama i uvjetima za izvršenje ugovora je ta što za razliku od tehničkih specifikacija, uvjeti za izvršenje ugovora ne dopuštaju isključenje ponuditelja na temelju očekivanog neispunjavanja obveza. ${ }^{88}$

\subsection{Trošak životnog vijeka}

Trošak životnog vijeka koncept je koji se oslanja na pretpostavku da sama cijena ne odražava financijsku i nefinancijsku korist koju pružaju socijalno i okolišno preferirana dobra, radovi ili usluge tijekom životnog vijeka njihova korištenja te je trošak životnog vijeka alat kojim se procjenjuje trošak dobra, robe ili usluge tijekom cijelog njenog životnog vijeka. ${ }^{89} \mathrm{U}$ kontekstu održive javne nabave, trošak životnog vijeka vrlo je važan element u izdizanju javne nabave iz isključive odrednice najniže cijene kao kriterija odabira. Iako mnogi naručitelji unutar EU koriste trošak životnog vijeka kao alat $\mathrm{u}$ donošenju odluke u postupcima javne nabave, korištenje tog alata ipak je daleko od sistematske uporabe. ${ }^{90}$

U novom regulatornom okviru i Direktivi 2014/24/EU trošak životnog vijeka

84 Članak 57. stavak 3. Direktive 2014/24/EU.

85 Paragraf 100. Direktive 2014/24/EU.

86 Članak 57. stavak 4. Direktive 2014/24/EU.

87 Članak 70. Direktive 2014/24/EU.

88 Dragos, Neamtu, op. cit. (bilj. 27.), str. 16.

89 Dragos, D. C., Neamtu, B., Sustainable Public Procurement:

Life-Cycle Costing in the New EU Directive Proposal, European procurement and public private partnership law review, vol. 1., 2013., str. 20. 
moguće je primjenjivati i kod ekonomski najpovoljnije ponude, ali i najniže cijene. Bitno je naglasiti kako metoda troška životnog vijeka nije obvezna, i naručitelji samostalno od slučaja do slučaja odlučuju hoće li ju primijeniti u predmetnim postupcima javne nabave. Jedan od glavnih motiva proširivanja uloge troška životnog vijeka u novom regulatornom okviru je i činjenica da se metoda troška životnog vijeka vrlo rijetko koristi u postupcima javne nabave unutar EU-a. Izvan EU-a, SAD, Japan, Švicarska i Norveška jedine su države koje dosljedno primjenjuju metodu troška životnog vijeka kao bitan element održive javne nabave. ${ }^{91}$

Trošak životnog vijeka uređen je člankom 68. Direktive 2014/24/EU. Pod troškove životnog vijeka ubrajaju se troškovi koje snosi sam naručitelj ili drugi korisnici, ali i vanjski troškovi. Pod troškove koje snosi sam naručitelj (ili drugi korisnici) ubrajaju se troškovi nabave, troškovi uporabe kao što je potrošnja energije i drugih resursa, troškovi održavanja i troškovi kraja životnog vijeka kao što su troškovi prikupljanja i recikliranja. ${ }^{92}$ Vanjski troškovi su troškovi pripisani okolišnim vanjskim učincima povezanim s proizvodom, uslugom ili radovima tijekom njihovog životnog vijeka, ako se može odrediti i provjeriti njihova novčana vrijednost. Takvi troškovi mogu uključivati troškove emisije stakleničnih plinova i emisije drugih zagađivača te ostale troškove zbog ublažavanja klimatskih promjena. ${ }^{93}$ Ako se naručitelj odluči procjeniti troškove korištenjem pristupa troškova životnog vijeka, u dokumentaciji o nabavi mora navesti podatke koje trebaju dostaviti ponuditelji i metodu koju će koristiti za određivanje troškova životnog vijeka na temelju tih podataka. Takva metoda mora ispunjavati sljedeće uvjete: mora se temeljiti na kriterijima koji se mogu objektivno provjeriti i koji nisu diskriminirajući. Posebice, ako nije utvrđena za višekratnu ili trajnu uporabu, ne smije neopravdano davati prednost ili stavljati u nepovoljniji položaj određene gospodarske subjekte; mora biti dostupna svim zainteresiranim stranama; i da tražene podatke mogu, uz razumno nastojanje, dostaviti prosječno pažljivi gospodarski subjekti, uključujući gospodarske subjekte iz trećih zemalja koje su stranke GPA-a ili drugih međunarodnih sporazuma koji obvezuju EU ${ }^{94} \mathrm{Cijeli}$ članak 68. odnosi se samo na ekološki aspekt održive javne nabave. Socijalni aspekt se ne spominje u kontekstu troškova životnog vijeka. Budući da postoje određeni socijalni aspekti koji bi se mogli procjenjivati tom metodom, kao što su uvjeti rada, jednakost zapošljavanja, troškovi zdravstvenog osiguranja za zaposlene i sl. ${ }^{95}$ nadamo se da će se u budućnosti i to razmotriti.

\subsection{Oznake}

Direktiva 2014/24/EU definira oznake kao svaki dokument, potvrdu ili certifikat kojim se potvrđuje da su određeni radovi, proizvodi, usluge, procesi ili postupci zadovoljili određene zahtjeve; a zahtjeve za oznaku kao zahtjeve koje određeni radovi,

91 Dragos, Neamtu, op. cit. (bilj. 27.), str. 19.

92 Članak 68. stavak 1. točka a) Direktive 2014/24/EU.

93 Članak 68. stavak 1. točka b) Direktive 2014/24/EU.

94 Članak 68. stavak 2. Direktive 2014/24/EU.

95 Dragos, Neamtu, op. cit. (bilj. 27.), str. 20. 
proizvodi, usluge, procesi ili postupci moraju ispuniti da bi dobili dotičnu oznaku. ${ }^{96}$ Bitno je napomenuti kako, sukladno i prije prikazanoj Max Havelaar presudi, oznake mogu biti okolišne (i označavati da proizvod zadovoljava određene okolišne standarde) ili socijalne (čime se dokazuje socijalno osjetljiva narav proizvodnog procesa proizvoda.)

Direktiva 2014/24/EU pruža mogućnost referiranja na određene ekološke ili socijalne oznake u tehničkim specifikacijama. Navedena mogućnost uređena je člankom 43., gdje je propisano da ako javni naručitelji namjeravaju kupiti radove, robu ili usluge s određenim okolišnim, društvenim ili drugim značajkama, mogu u tehničkim specifikacijama, kriterijima za dodjelu ili uvjetima za izvršenje ugovora zahtijevati određene oznake kao dokaz da radovi, usluge ili roba odgovaraju traženim obilježjima, pod uvjetom da su ispunjeni svi sljedeći uvjeti: da se zahtjevi za oznaku tiču samo kriterija koji su povezani s predmetom ugovora i prikladni su za utvrđivanje značajki radova, robe ili usluga koji su predmet ugovora; da se zahtjevi za oznaku temelje na kriterijima koji se mogu objektivno provjeriti i koji nisu diskriminirajući; $\mathrm{da}$ su oznake utvrđene $\mathrm{u}$ otvorenom i transparentnom postupku u kojem mogu sudjelovati sve zainteresirane strane kao što su državna tijela, potrošači, socijalni partneri, proizvođači, distributeri i nevladine organizacije; da su oznake dostupne svim zainteresiranim stranama i da zahtjeve za oznaku određuje treća strana nad kojom gospodarski subjekt koji zahtijeva dodjelu oznake ne može vršiti odlučujući utjecaj..$^{97}$ Bitno je napomenuti kako sada javni naručitelji imaju pravo zahtijevati točno određene oznake sa specifikacijama koje su im bitne u postupku javne nabave, što će bitno pomoći javnim naručiteljima u provođenju održivih postupaka javne nabave. ${ }^{98}$ Ipak, javni naručitelji neće imati apsolutne diskrecijske ovlasti kod biranja oznaka, već će morati prihvatiti i jednakovrijednu oznaku ako ju ponuditelj priloži. ${ }^{99}$

Ako gospodarski subjekt evidentno nije mogao pribaviti određenu oznaku koju je javni naručitelj naveo ili jednakovrijednu oznaku u okviru određenih rokova iz razloga koji se ne mogu pripisati gospodarskom subjektu, javni naručitelj prihvaća druge prikladne načine za dokazivanje, koji mogu uključivati tehničku dokumentaciju proizvođača, pod uvjetom da dotični gospodarski subjekt dokaže da radovi, roba ili usluge koje on treba pružiti ispunjavaju zahtjeve za određenu oznaku ili određeni zahtjev koji je naveo javni naručitelj. ${ }^{100}$ Navedena odredba predstavlja obvezu javnih naručitelja da koriste takozvano načelo tehničke neutralnosti, u kojem moraju prihvatiti ponude od ponuditelja koji dokažu da zadovoljavaju tehničke uvjete, pa tako i uvjeta iz oznaka, iako iz objektivnih razloga njihov proizvod nema navedenu ili jednakovrijednu oznaku. ${ }^{101}$ Graells navodi kako je glavni cilj načela tehničke

96 Članak 2. stavak 1. točke 23. i 24. Direktive 2014/24/EU.

97 Članak 43. stavak 1. Direktive 2014/24/EU.

98 Caranta, R., Labels as enablers of sustainable public procurement, Sustainable public procurement under EU law, Cambridge University Press, 2016., str. 109.

99 "Javni naručitelji koji zahtijevaju posebnu oznaku prihvaćaju svaku oznaku koja potvrđuje da radovi, roba ili usluge zadovoljavaju zahtjev za jednakovrijednu oznaku.”, članak 43. stavak 1. Direktive 2014/24/EC.

100 Članak 43. stavak 1. Direktive 2014/24/EU.

101 Graells, A. S., Public procurement and the EU competition rules, Hart Publishing, 2015., str. 
neutralnosti izbjegavanje stvaranja neopravdanih prepreka otvaranju postupaka javne nabave tržišnom natjecanju. Stoga bi javni naručitelji trebali izbjegavati pretjerano specifične ili diskriminatorne tehničke specifikacije, što se odnosi i na oznake, ali i na troškove životnog vijeka proizvoda. ${ }^{102}$ Dakle, iako proizvod određenog ponuditelja (bez vlastite krivnje) nema oznaku koju je javni naručitelj tražio u okviru tehničkih specifikacija, javni naručitelj mu sukladno načelu tehničke neutralnosti mora omogućiti sudjelovanje u javnonabavnom postupku.

Ekološke oznake uređene su Uredbom 2010/66/EC, kojom je korištenje oznaka uređeno na dobrovoljnoj osnovi, čija je namjera promicanje proizvoda koji zadovoljavaju visoke ekološke standarde. Uredba promiče korištenje ekoloških oznaka kako bi se izbjeglo širenje broja različitih oznaka za istu, ekološku svrhu, i kako bi se potaknulo korištenje ekoloških standarda u svim sektorima u kojima okolišni utjecaj može biti faktor u odlukama potrošača. ${ }^{103}$ Ipak, naručitelji se mogu referirati i na druge istovrsne oznake, budući da bi obvezatna primjena okolišnih oznaka bila diskriminatorna prema potencijalnim ponuditeljima. ${ }^{104}$

\section{ODRŽIVA JAVNA NABAVA U REPUBLICI HRVATSKOJ}

Aktualni pravni sustav javne nabave u Republici Hrvatskoj temelji se na Zakonu o javnoj nabavi ${ }^{105}$ (u nastavku rada: ZJN). Kako ZJN još uvijek nije prilagođen javnonabavnom regulatornom okviru EU-a iz 2014., u njemu se nalaze odredbe prilagođene prethodnom regulatornom okviru iz 2004. Sadašnji ZJN sadrži niz odredaba u kojima su sadržani i socijalni i okolišni elementi održive javne nabave.

Tako se člankom 15. uređuje mogućnost određivanja rezerviranih ugovora, u kojem primjećujemo elemente socijalne osjetljivosti. Naručitelji mogu rezervirati pravo sudjelovanja u postupcima javne nabave zaštitnim radionicama ili omogućiti da se ugovori izvršavaju u kontekstu zaštićenih programa zapošljavanja ako su većina zaposlenih u odnosu na ukupan broj zaposlenih osobe $s$ invaliditetom koje zbog prirode ozbiljnosti njihova invaliditeta ne mogu obavljati zanimanja u redovitim uvjetima. U pozivu na nadmetanje u takvim postupcima javne nabave naručitelj mora naznačiti da je postupak javne nabave rezerviran isključivo za te gospodarske subjekte. Gospodarski subjekti koji ispunjavaju uvjete za sklapanje rezerviranih ugovora mogu najviše $20 \%$ vrijednosti rezerviranog ugovora dati podizvoditeljima koji ne ispunjavaju te iste uvjete. Kod dokazivanje tehničke i stručne sposobnosti, naručitelju se ostavlja mogućnost da kao jedan od uvjeta postavi, samo u opravdanim slučajevima, navod o mjerama za upravljanje okolišem koje će gospodarski subjekt biti u mogućnosti primjenjivati pri izvršenju ugovora. ${ }^{106}$ Navedena mogućnost postoji ako su predmet nabave radovi ili usluge, ali ne i roba. Ako se naručitelj odluči za navode o mjerama za upravljanje okoliša kao jedan od dokaza tehničke

334.

102 Ibid., str. 453.

103 Dragos, Neamtu, op. cit. (bilj. 27.), str. 20.

104 Ibid.

105 NN, br. 90/11, 83/13, 143/13, 13/14.

106 Članak 72. stavak 4. točka 4. i stavak 5. točka 6. ZJN-a. 
i stručne sposobnosti, može zahtijevati i prilaganje certifikata koji bi to dokazivali. U tom slučaju, javni naručitelj mora uputiti na Sustav Zajednice za upravljanje okolišem (Community Eco-Management and Audit Scheme, EMAS) ili na određene hrvatske norme za sustave upravljanja okolišem kojima su prihvaćene europske ili međunarodne norme. Sustavi upravljanja okolišem na koje upućuje javni naručitelj moraju biti potvrđeni (certificirani) od tijela koja udovoljavaju propisima Republike Hrvatske koji su usklađeni s pravom Europske unije ili hrvatskim normama kojima su prihvaćene europske ili međunarodne norme za osposobljenost tijela koja potvrđuju sustave upravljanja okolišem. ${ }^{107}$ Također, naručitelj mora priznati jednakovrijedne potvrde (certifikate) o sukladnosti sustava upravljanja okolišem izdane od tijela osnovanih u drugim državama članicama, kao i druge dokaze o jednakovrijednim mjerama upravljanja okolišem. ${ }^{108}$

Kod određivanja tehničkih specifikacija predmeta nabave postoji nekoliko mjesta gdje se spominju održivi elementi. Uz uvodnu odredbu kojom se određuje da ako je moguće tehničke specifikacije moraju uključiti rješenje za dostupnost osobama $\mathrm{s}$ invaliditetom ili rješenje za sve korisnike ${ }^{109}$, odredbe o formuliranju tehničkih specifikacija sadrže i elemente održive javne nabave.

Tako se tehničke specifikacije mogu formulirati i u obliku izvedbenih ili funkcionalnih zahtjeva koji mogu uključivati karakteristike koje se odnose na zaštitu okoliša povezane s predmetom nabave. Pritom parametri moraju biti dovoljno precizni za ponuditelje da dobiju jasnu predodžbu o predmetu nabave, a za naručitelje da sklope ugovor. ${ }^{110}$ Ako naručitelj određuje tehničke specifikacije s okolišnim elementima, on može koristiti detaljne specifikacije ili, po potrebi, njihove dijelove, kako su definirane europskim, nacionalnim, višenacionalnim, ili bilo kojim drugim ekološkim oznakama, pod uvjetom da su: te specifikacije prikladne za definiranje značajki robe ili usluga koje su predmet nabave, zahtjevi za oznaku sastavljeni na temelju znanstvenih podataka, ekološke oznake prihvaćene na temelju postupka u kojem mogu sudjelovati sve zainteresirane strane, kao što su vladina tijela, potrošači, proizvođači, distributeri i organizacije za zaštitu okoliša, dostupne svim zainteresiranim stranama. ${ }^{11}$

Ako se odluči za korištenje ekoloških oznaka kao metode dokazivanja tehničkih specifikacija, naručitelj može naznačiti da se za one proizvode i usluge koje nose ekološku oznaku pretpostavlja da zadovoljavaju tehničke specifikacije određene u dokumentaciji za nadmetanje, ali i mora prihvatiti bilo koje drugo prikladno sredstvo dokazivanja. ${ }^{112}$ Kao jedan od posebnih uvjeta za izvršenje ugovora o javnoj nabavi, naručitelj može odrediti posebne uvjete vezane za izvršenje ugovora koji se mogu odnositi posebice na socijalna i pitanja zaštite okoliša, pod uvjetom da su u vezi s predmetom nabave i da nisu izravno ili neizravno diskriminirajući. Ako se odluči za navedenu mogućnost, naručitelj određuje u pozivu na nadmetanje ili u dokumentaciji za nadmetanje pri opisu predmeta nabave, određivanja tehničkih specifikacija, kriterija

107 Članak 74. stavak 1. ZJN-a.

108 Članak 74. stavak 2. i 3. ZJN-a.

109 Članak 81. stavak 1. ZJN-a.

110 Članak 81. stavak 3. točka 2. ZJN-a.

111 Članak 81. stavak 6. ZJN-a.

112 Članak 81. stavak 7. ZJN-a. 
za odabir ponude ili uvjeta ugovora. ${ }^{113}$

Naručitelj može i u dokumentaciji za nadmetanje navesti podatke o tijelima od kojih natjecatelj ili ponuditelj može dobiti pravovaljanu informaciju o obvezama koje se odnose na poreze, zaštitu okoliša, odredbe o zaštiti radnoga mjesta i radne uvjete koje su na snazi u području na kojem će se izvoditi radovi ili pružati usluge i koje će biti primjenjive na radove koji se izvode ili na usluge koje će se pružati za vrijeme trajanja ugovora. Ako se odlučio navesti te podatke u dokumentaciji za nadmetanje, javni naručitelj mora tražiti od ponuditelja ili natjecatelja u postupku javne nabave da navedu da su pri sastavljanju ponude uzeli u obzir obveze koje se odnose na poreze, zaštitu okoliša, odredbe o zaštiti radnoga mjesta i radne uvjete koje su na snazi u mjestu gdje će se izvoditi radovi ili na kojem će se pružati usluge. ${ }^{114}$

Elementi održivosti nalaze se i kod utvrđivanja neuobičajeno niske cijene. Naručitelju se daje mogućnost odbijanja ponude ako sumnja u neuobičajeno nisku cijenu. Ipak, prije odbijanja ponude mora pružiti mogućnost ponuditelju da se o tomu očituje. U sklopu tog očitovanja naručitelj može tražiti dostavu određenih podataka, a ti se podaci mogu odnositi i na pridržavanje odredaba koje se odnose na poreze, zaštitu okoliša, zaštitu radnoga mjesta i radne uvjete koje su na snazi u mjestu na kojem će se izvoditi radovi, pružati usluge ili isporučivati roba. ${ }^{115}$

U trenutku pisanja ovoga rada (prosinac 2016.) još uvijek je na snazi ZJN iz 2011. Ministarstvo gospodarstva skoro godinu dana pokušavalo je završiti novi ZJN, koji bi implementirao trenutni javnonabavni regulatorni okvir EU-a, čije smo održive elemente prikazali u ovom radu. Novi ZJN je napokon usvojen u Saboru i objavljen je u Narodnim novinama te stupa na snagu 1. siječnja 2017. ${ }^{116}$ Kraćom analizom ZJN-a 2017. možemo vidjeti koliko je zakonodavac kvalitetno usvojio nove održive elemente javnonanavnog regulatornog okvira EU-a.

Tako su održivi elementi vezani za tehničke specifikacije kvalitetno preneseni u članke 207. i 209. ZJN-a 2017., održivi elementi kod kriterija za odabir ponude preneseni su člankom 284. ZJN-a 2017., održivi elementi kod mogućnosti isključenja ponuditelja implementirani su u članke 251., 252. i 253. ZJN-a 2017., održivi elementi u uvjetima za izvršenje ugovora implementirani su u članku 218. ZJN-a 2017., trošak životnog vijeka implementiran je u člancima 287. i 288. ZJN-a 2017., dok su oznake uređene člankom 212. ZJN-a 2017. Analiziravši navedene odredbe, primjećuje se kako su svi održivi elementi iz novog javnonabavnog regulatornog okvira EU doslovno preneseni u ZJN 2017. Ipak, i ovdje je bitno napomenuti kako ni u ZJN-u 2017. nema načina kako bi se naručitelji prisilili koristiti održive elemente u postupcima javne nabave, te su svi ovi održivi elementi i dalje samo dobrovoljni.

Dosada, a vjerujemo kako će to biti slučaj i nakon stupanja na snagu novog ZJN-a, implementacija održivih elemenata u postupke javne nabave u Republici Hrvatskoj nije bila na zavidnoj razini. Te činjenice svjesno je i Ministarstvo zaštite okoliša i prirode (u nastavku rada: Ministarstvo), koje upravo iz tog razloga

113 Članak 83. ZJN-a.

114 Članak 84. ZJN-a.

115 Članak 91. stavak 3. točka 4. ZJN-a.

116 NN, br. 120/16. (u nastavku rada: ZJN 2017.) 
2015. donosi Nacionalni akcijski plan za zelenu javnu nabavu ${ }^{117}$ (u nastavku rada: NAPZJN). U donošenju NAPZJN-a sudjelovalo je i Povjerenstvo za zelenu javnu nabavu (u nastavku: PZJN), koje je Ministarstvo osnovalo upravo radi donošenja NAPZJN-a, ali i za njegovo praćenje i provedbu, kao i predlaganje mjera aktivnosti zelene javne nabave te izradu prijedloga stajališta Republike Hrvatske na temu zelene javne nabave prema Europskoj komisiji i Ujedinjenim narodima. ${ }^{18}$ Svrha NAPZJN-a je da se sustavom javne nabave u Republici Hrvatskoj potakne nabava proizvoda i usluga koje imaju manji okolišni otisak (negativni utjecaj na okoliš) u odnosu na istovrsne proizvode i usluge, odnosno definiranje aktivnosti koje će dovesti do toga. Time tijela javne uprave mogu doprinijeti smanjenju svog okolišnog otiska kojeg uzrokuju svojim poslovanjem. ${ }^{119}$ NAPZJN se odnosi na razdoblje od 2015. do 2017., na temelju kojeg će se donijeti novi za razdoblje do kraja 2020. godine. Glavni cilj NAPZJN-a je ambiciozan. Namjerava se postići $50 \%$ provedenih postupaka javne nabave u Republici Hrvatskoj uz primjenu zelenih mjerila do 2020. godine. Koliko je taj cilj ambiciozan pokazuje $i$ terminski plan sklapanja ugovora zelene javne nabave do 2020., gdje nalazimo podatak kako se procjenjuje kako je 2015., od ukupno 25000 postupaka javne nabave u Republici Hrvatskoj, samo oko 1000 sadržavalo okolišne elemente (što čini otprilike četiri posto od ukupnog broja.) ${ }^{120}$ Kako bi taj plan imao ikakve šanse za uspjeh, nužno je identificirati prioritetne skupine proizvoda i usluga na koje se zelena javna nabava mora koncentrirati. Budući da su iskustva drugih država članica EU-a, koje su već ranije implementirale zelenu javnu nabavu pokazala kako su najpogodnije kategorije proizvoda za implementaciju zelenih mjerila papir za ispis, kopiranje i grafički papir, uredska i informatička oprema (IT oprema) i motorna vozila, predlaže se da se i u NAPZJN-u te kategorije odaberu kao prioritetne zbog prihvaćenosti zelenih mjerila u postupcima javne nabave. ${ }^{121}$ NAPZJN navedene kategorije malo proširuje te kao prioritetne navodi papir za ispis i kopiranje, motorna vozila, električnu energiju, usluge čišćenja, telekomunikacijske usluge i usluge mobilne telefonije zajedno s uređajima, uredsku i informatičku oprema. ${ }^{122}$ Navedene ciljeve Ministarstvo namjerava ostvariti opsežnim promocijskim aktivnostima, program usavršavanja provoditelja postupaka javne nabave, ali i posredno implementacijom javnonabavnog regulatornog okvira EU-a iz 2014. Navedeni plan treba pozdraviti, kao što i treba pozdraviti strateško razmišljanje i uvažavanje činjenice da se javnom nabavom mogu ostvariti i ovako važni sekundarni ciljevi.

Bitno je napomenuti i kako je PZJN imao značajne aktivnosti u promicanju korištenja ekoloških elemenata u postupcima javne nabave. S aktivnostima PZJN-a izloženima u nastavku upoznati smo na temelju odgovora Ministarstva na naš zahtjev radi ostvarivanja prava na pristup informacijama. PZJN je osnovan 17. prosinca

117 Nacionalni akcijski plan za zelenu javnu nabavu, http://mzoip.hr/doc/nacionalni_akcijski_ plan_za_zelenu_javnu_nabavu.pdf, (24. prosinca 2015.).

118 Odgovor Ministarstva na zahtjev radi ostvarivanja prava na pristup informacijama, KLASA: 008-01/16-01/198, URBROJ: 517-01-16-4, od 19. prosinca 2016., str. 1.

119 NAPZJN, str. 7.

120 NAPZJN, str. 15.

121 NAPZJN, str. 14.

122 NAPZJN, str. 18. 
2014., imenovan je na razdoblje od četiri godine i dosada je održano devet sjednica. ${ }^{123}$ Aktivnosti PZJN-a u dosadašnjem razdoblju sastojale su se od četiri područja: izobrazbe, uključivanja mjerila zelene javne nabave, promidžbe zelene javne nabave i provedbe zelene javne nabave.

U okviru izobrazbe u području javne nabave u 2015. i u okviru djelatnosti Ministarstva gospodarstva (jedan član PZJN-a djelatnik je Ministarstva gospodarstva) održano je 60 specijalističkih programa koje je pohađalo 1033 polaznika, a jedna od tema tih programa bila je i zelena javna nabava. ${ }^{124}$ Neki od programa koji su odobreni za 2016. su: Zelena javna nabava i e-dostava i Zelena javna nabava i praksa. Također, Državna škola za javnu upravu nudi programe usavršavanja državnih službenika kao što su: Alati za upravljanje zelenom javnom nabavom i Proces zelene javne nabave s posebnim osvrtom na post proceduralnu fazu i primjeri najbolje prakse. ${ }^{125}$ PZJN posebno naglašava kako su trenutno u postupku realizacije projekti Usluga izobrazbe iz područja javne nabave o mjerilima zelene javne nabave i Program usavršavanja o zelenoj javnoj nabavi za provoditelje postupaka javne nabave, u sklopu kojih će se provoditi besplatna izobrazba. ${ }^{126}$

Članica PZJN-a iz Državnog ureda za središnju javnu nabavu navodi kako su tijekom 2015. provedena četiri postupka javne nabave uz primjenu mjerila zelene javne nabave, čija je kombinirana vrijednost bila 8.669.843,15 kn bez PDV-a. ${ }^{127}$ Radi poticanja primjene ekoloških mjera u postupcima javne nabave, članovi PZJN-a osmislili su Anketni upitnik za zelenu javnu nabavu, koji je zajedno s poveznicom na NAPZJN distribuiran na 6274 e-mail adresa naručitelja registriranih u Elektroničkom oglasniku javne nabave, na koji je pristiglo 629 odgovora. ${ }^{128}$ Poziv na ispunjavanje iste ankete planiran je i na kraju provedbe NAPZJN-a te će se tada usporediti rezultati prve i druge ankete. ${ }^{129}$ Bitno je napomenuti kako su članovi PZJN-a uspjeli uvrstiti mjere zelene javne nabave i u strateški dokument Grada Zagreba ZAGREBPLAN 2020+. ${ }^{130}$ Kako članovi PZJN-a dolaze i iz Hrvatske zajednice županija, Udruge općina u Republici Hrvatskoj i Udruge gradova Republike Hrvatske, predložili su primjer Grada Zagreba podijeliti sa svojim članovima. ${ }^{131}$ Također, na inicijativu članice PZJN-a unutar Ministarstva poduzetništva i obrta dogovoreno je da svi budući postupci javne i bagatelne nabave sadrže mjerila zelene javne nabave, te je u tom smislu u tijeku izmjena Upute o planiranju i provedbi postupaka javne nabave u Ministarstvu poduzetništva i obrta u sklopu koje će se propisati korištenje mjerila zelene javne nabave kada god je to moguće. ${ }^{132}$

123 Odgovor Ministarstva na zahtjev radi ostvarivanja prava na pristup informacijama, KLASA: 008-01/16-01/198, URBROJ: 517-01-16-4, od 19. prosinca 2016., str. 1.

124 Ibid., str. 2.

125 Ibid.

126 Ibid.

127 Ibid., str. 3.

128 Ibid., str. 4.

129 Ibid.

130 Ibid.

131 Ibid.

132 Ibid. 
U sklopu promidžbe zelene javne nabave Ministarstvo je, u suradnji s PZJNom, tiskalo NAPZJN u 500 primjeraka i distribuiralo ga tijelima državne uprave, županijama i većim gradovima, sektorskim naručiteljima i tijelima nadležnim Ministarstvu te je uspostavljen i portal za zelenu javnu nabavu (www.zjn.hr). ${ }^{133}$ Provedbu i implementiranje elemenata zelene javne nabave PZJN prati putem elektroničkog oglasnika javne nabave i putem prije navedenog anketnog upitnika.

Nažalost, takav ozbiljan pristup ne vidimo i kod uključivanja socijalnih elemenata u postupke javne nabave. Izostanak bilo kakve inicijative za poticanjem uključivanja socijalnih elemenata u postupke javne nabave može predstavljati značajan problem, budući da potražnja javnih naručitelja kroz postupke javne nabave, kada je orijentirana na inovativna rješenja i proizvode, ima potencijal unaprijediti kvalitetu javnih usluga koje su dostupne građanima. ${ }^{134}$ To se prije svega odnosi na činjenicu da socijalni javnonabavni elementi mogu potaknuti određene socijalne inovacije, odnosno razvoj novih ideja koje mogu potaknuti rast kvalitete života građana ${ }^{135}$, ali i da mogu proizvesti veću vrijednost za javnu potrošnju istovremeno ispunjavavši ekonomske, ali i socijalne ciljeve javne nabave. ${ }^{136}$ Isto tako, bitno je napomenuti kako su općenito na razini EU-a okolišni elementi značajno više uključeni u postupke javne nabave nego socijalni. Jedan od glavnih razloga za takav razvoj događaja načelna je zabrana diskriminacije ponuditelja na temelju neekonomskih kriterija koji nisu povezani s predmetom nabave javnonabavnog postupka. ${ }^{137}$ Težina dokazivanja da su socijalni uvjeti usko vezani za nabavu dobra ili usluge jedan je od glavnih razloga zašto javni naručitelji ne uključuju socijalne kriterije u javnonabavne postupke. ${ }^{138}$

$\mathrm{U}$ teoriji tako u zadnje vrijeme postoje i prijedlozi za obvezno uključivanje socijalnih kriterija u postupke javne nabave. Tako Wiesbrock zastupa tezu kako je to nužno iz tri razloga; smatra kako socijalni kriteriji u javnonabavnim postupcima $\mathrm{u}$ okviru EU moraju biti dio svake javnonabavne aktivnosti, a ne nešto što se ostavlja u diskreciji država članica i javnih naručitelja. ${ }^{139}$ Dalje, smatra kako čim se donese normativni izbor da se u postupcima javne nabave promiču i neki drugi ciljevi osim ekonomskih, individualne odredbe se više ne smiju baviti pitanjem jesu li takve odredbe poželjne, već samo pitanjem kako ih efektivno koristiti. ${ }^{140}$ Zaključno, smatra kako socijalni kriteriji nisu u suprotnosti s ostalim ciljevima javne nabave. ${ }^{141}$

Ipak, ako odlučimo ostati unutar javnonabavnog regulatornog okvira EU-a, koji

133 Ibid., str. 5.

134 Edler., J., Georghiou, L., Public procurement and innovation, Ressurecting the demant side, Research policy 36 (2007), http://dimetic.dime-eu.org/dimetic_files/EdlerGeorghiou2007.pdf, pristupljeno 7. prosinca 2016., str. 949.

135 Poll, E., Ville, S., Social innovation: Buzz word or enduring term?, Journal of Socio-Economics, 38 (6), http://ro.uow.edu.au/cgi/viewcontent.cgi?article=1699\& context=commpapers, pristupljeno 7. prosinca 2016., str. 7.

136 Barraket, J., Keast, R., Furneaux, C., op. cit. (bilj. 20.), str. 44.

137 Wiesbrock, A., Socially responsible public procurement, European value or national choice?, Sustainable public procurement under EU law, Cambridge University Press, 2016., str. 76.

138 Ibid.

139 Ibid., str. 77.

140 Ibid.

141 Ibid. 
korištenje održivih kriterija ostavlja u diskreciji naručitelja, potrebno je naći rješenja unutar postojećih pravnih pravila. Ministarstvo zaštite okoliša pristupilo je problemu na konstruktivan način, te bi se na vrlo sličan način moglo potaknuti uključivanje socijalnih elemenata u postupke javne nabave. Ministarstvo za demografiju, obitelj, mlade i socijalnu politiku (u nastavku: MDOMSP) također bi moglo donijeti sličan nacionalni plan, radi ostvarivanja uvrštavanja socijalnih kriterija u postupke javne nabave. Poseban naglasak u takvom planu trebalo bi staviti na nekoliko elemenata; kod kriterija za odabir ponude trebalo bi se poticati davanje prednosti ponuditeljima koji zapošljavaju određeni postotak socijalno ugroženih skupina građana. Tu ponajprije mislimo na zapošljavanje dugoročno nezaposlenih osoba sukladno evidencijama Hrvatskog zavoda za zapošljavanje, članove ugroženih manjinskih skupina (npr. članovi romske zajednice u Republici Hrvatskoj), zapošljavanje osoba s invaliditetom, ali i davanje prednosti ponuditeljima koji imaju povoljniji omjer zaposlenih muškaraca i žena. Također, trebalo bi poticati odabir ponuditelja čiji proizvodi imaju određene socijalne oznake.

Iako korištenje socijalnih javnonabavnih elemenata nije obvezatno, takvim nacionalnim planom bi se obrazovanjem javnih naručitelja, ali i provođenjem promocijskih aktivnosti podigla svijest o društveno odgovornim postupcima javne nabave te bi se ukazalo i na širu društvenu pa i ekonomsku korist od takvih javnonabavnih postupaka. Takva kontinuirana djelatnost MDOMPS-a sigurno bi pozitivno utjecala na osvještavanje javnih naručitelja, ali i šire javnosti o širokoj društvenoj korisnosti socijalnih održivih aspekata javne nabave te bi povećala postotak javnonabavnih postupaka u kojima bi socijalni elementi bili implementirani.

\section{ZAKLJUČAK}

Održiva javna nabava, iako je relativno star pravni koncept, počinje se značajnije uobličavati tek u posljednjih tridesetak godina. Velika kupovna moć države i važnost postupaka javne nabave za svako tržište nužno su doveli do osvještavanja korištenja javne nabave i za ostvarivanje sekundarnih, socijalnih i okolišnih ciljeva. Kao takva, održiva javna nabava sigurno ima više prednosti nego nedostataka. Posredno korištenje javne nabave kao sredstva u ostvarivanju bolje zaštite okoliša i veće uključenosti socijalno ugroženih skupina u društvu mora se podržati. Ipak, ostvarivanje navedenih ciljeva mora se pomiriti s nabavom najkvalitetnijih dobara, usluga ili radova uz najmanje moguće troškove za državni proračun.

Često se institutu održive javne nabave prigovara činjenica da se tako dodatno komplicira već ionako složen postupak javne nabave i smanjuje transparentnost, da se tako može narušavati ostvarivanje cilja učinkovitog trošenja javnih sredstava, te da je teško pratiti učinke ostvarenja socijalnih i okolišnih ciljeva. Navedeni prigovori postat će još važniji konačnom implementacijom javnonabavnog regulatornog okvira EU-a iz 2014., gdje se puno veći naglasak stavlja na kriterij ekonomski najpovoljnije ponude.

Kada se koncept održive javne nabave kritizira isticanjem povećanja složenosti postupaka i poskupljivanja samog postupka javne nabave (odabirom skupljeg 
ponuditelja, ali ponuditelja koji ispunjava održive standarde), potrebno je istaknuti nekoliko činjenica. Smatramo kako je uključivanje održivih elemenata u postupke javne nabave ne samo korisno i nužno za omogućavanje održivog razvoja, već i obveza uspostavljena Ugovorima EU-a. ${ }^{142}$

Prije svega, iako je jedan od glavnih motiva za osnivanje EU-a ostvarenje zajedničkog i slobodnog tržišta, EU nije samo ekonomsko-tržišna zajednica. U srž EU-a utkane su i ideje održivog razvoja i zaštite ljudskih prava, kao temeljne odrednice specifičnog ekonomskog razvoja koje EU želi postići. Takve ideje postoje i u Ugovoru o funkcioniranju EU, čiji članak 3. stavak 3. navodi kako "Unija uspostavlja unutarnje tržište. Ona radi na održivom razvoju Europe koji se temelji na uravnoteženom gospodarskom rastu i stabilnosti cijena, visoko konkurentnom socijalnom tržišnom gospodarstvu, s ciljem pune zaposlenosti i društvenog napretka, te visokoj razini zaštite i poboljšanja kvalitete okoliša. Ona promiče znanstveni i tehnološki napredak. Ona suzbija društvenu isključenost i diskriminaciju, promiče socijalnu pravdu i zaštitu, ravnopravnost žena i muškaraca, međugeneracijsku solidarnost i zaštitu prava djeteta."

Navedeni članak jasno ocrtava opredjeljenje EU-a za održivim razvojem te odbacuje isključivo ekonomske razvojne motive, i uključuje i okolišne i socijalne elemente. Također, članak 11. navodi kako "zahtjevi u pogledu zaštite okoliša moraju se uključiti u utvrđivanje i provedbu politika i aktivnosti Unije, posebice s ciljem promicanja održivog razvoja." Navedeni članci pokazuju želju osnivača EU da ciljeve ekonomskog razvoja i razvoja slobodnog tržišta dovedu u ravnotežu s drugim, također važnim ciljevima - ciljevima zaštite okoliša i progresivnim socijalnim ciljevima.

Stoga ne čudi kada Kingston zaključuje kako EU na ustavnoj razini ne samo da priznaje važnu povezanost ekonomskih i okolišnih (i socijalnih, op. a.) politika, već i zahtijeva njihovu ravnotežu. ${ }^{143}$ Ipak, bitno je napomenuti kako je EU navedena ustavna načela često zanemariva i prigodno prešućiva u područjima gdje bi uspostavljanje navedene ravnoteže negativno utjecalo na ekonomske ciljeve. ${ }^{144}$ Održive elemente u novom javnonabavnom regulatornom okviru EU iz 2014. svakako vidimo kao pokušaj uspostavljanja te ravnoteže ali činjenica da je u diskreciji naručitelja hoće li te elemente uključiti u svoj javnonabavni natječaj ponovno ukazuje na zadršku u ostvarivanju tog cilja.

Kritika s kojom se možemo složiti je ona u kojoj se navodi kako je jako teško pratiti učinke održive javne nabave, odnosno kako je jako teško pratiti socijalne i okolišne učinke. Budući da je socijalni i okolišni učinak održive javne nabave gotovo uvijek posredan, jako je teško uspostaviti izravni sustav praćenja učinaka održive javne nabave na zaštitu okoliša i socijalnu inkluzivnost ugroženih skupina. Bez kvalitetnog sustava praćenja, jako je teško precizno utvrditi učinak navedenih postupaka. Postoji jako malo priznatih standarda za ekološke i socijalne kriterije, te povezanih sustava za certificiranje i jasnih kriterija koji bi mogli ukazati na činjenicu koji je oblik zaštite

142 Vidi i Sjafjell, B., Wiesbrock, A., Why should public procurement be about sustainability, Sustainable procurement under EU law, Cambridge University Press, 2016., str. 4.

143 Kingston, S., The uneasy relationship between EU environmental and economic policies, Sustainable procurement under EU law, Cambridge University Press, 2016., str. 25.

144 Ibid., str. 27. 
okoliša ili socijalnih interesa korisniji za društvo u cjelini. ${ }^{145}$

Održiva javna nabava ima i sve veću važnost u pravnom poretku EU-a, i stoga posljedično i sve veću važnost u pravnom poretku Republike Hrvatske. Počevši s regulatornim okvirom iz 2004. elementi održive javne nabave ulaze u pravne poretke svih država članica, dok se ti elementi značajno šire regulatornim okvirom i 2014. Bitno se proširuju određeni održivi elementi, dok se dodaju i neki novi. Tako najveće izmjene vidimo u tehničkim specifikacijama, kriterijima za odabir ponude, uvjetima za izvršenje ugovora, novom institutu troškova životnog vijeka, ali i ekološkim oznakama. Kao najveći problem u svemu tomu vidimo činjenicu da je implementacija održivih elemenata u postupke javne nabave još uvijek dobrovoljna, te nema načina kako prisiliti naručitelje da te elemente implementiraju u svoje javnonabavne natječaje. Ipak, svejedno smatramo kako će ti značajno prošireni elementi održive javne nabave u novom EU regulatornom okviru sigurno imati i značajan učinak na ostvarenje cilja Ministarstva od 50 \% zelenih javnih nabava do 2020. godine. Nove odredbe u kombinaciji s planiranim promocijskim aktivnostima i edukacijom zaposlenika unutar potencijalnih naručitelja mogu imati veliki utjecaj na osvješćivanje važnosti vođenja postupaka održive javne nabave. Ipak, razočaravajuća je činjenica da dio održive javne nabave koji se odnosi na ostvarivanje socijalnih ciljeva nije na sličan način prepoznat kao bitan u Republici Hrvatskoj.

\section{LITERATURA}

1. Barraket, J., Keast, R., Furneaux, C., Social procurement and new public governance, Routlege, 2016.

2. Brammer, S., Walker, H. L., Sustainable procurement practice in the public sector: An international comparative study, University of Bath Working Paper 2007, http://opus. bath.ac.uk/281/1/2007-16.pdf, pristupljeno 5. prosinca 2016.

3. Burgi, M., Brandmeier, B., Quality as an Interacting Award Criterion under Current and Future EU-Law, European procurement and public partnership law review, vol. 9., br. 1. 2014.

4. Caranta, R., Labels as enablers of sustainable public procurement, Sustainable public procurement under EU law, Cambridge University Press, 2016.

5. Caranta, R., Sustainable public procurement in the EU, The law of green and sustainable procurement in Europe, DJOF Publishing, 2010.

6. Conway, D. M., Sustainable Procurement Policies and Practices at the State and Local Government Level, Greening local government, K. Hirokawa \& P. Salkin, eds., 2012, https://papers.ssrn.com/sol3/papers.cfm?abstract_id=2095576, pristupljeno 1. prosinca 2016.

7. Dragicevic, N., Ditta, S., Community benefits and social procurement policies-A jurisdictional review, https://mowatcentre.ca/wp-content/uploads/publications/121_ community_benefits_and_social_procurement_policies.pdf, pristupljeno 5. prosinca 2016.

8. Dragos, D. C., Neamtu, B., Sustainable public procurement in the EU: experiences and prospects, u Modernising public procurement: the new Directive, DJOF Publishing, Copenhhagen 2014.

9. Dragos, D. C., Neamtu, B., Sustainable Public Procurement: Life-Cycle Costing in the

145 Poulsen, S. T., Jakobsen, P. S., Kalsmose-Hjelmborg S. E., EU public procurement law, DJOF Publishing, 2012., str. 303. 
New EU Directive Proposal, European procurement and public private partnership law review, vol. 1., 2013.

10. Edler, J., Georghiou, L., Public procurement and innovation, Ressurecting the demant side, Research policy, 36 (2007), http://dimetic.dime-eu.org/dimetic_files/ EdlerGeorghiou2007.pdf, pristupljeno 7. prosinca 2016.

11. Fisher, E., The Power of Purchase: Addressing Sustainability through Public Procurement, European procurement and public private partnership review, vol. 8, br. 1, 2013.

12. Ganley, S. D., "Green product" procurement polici in the European union: treatment of life cycle carbon analysis and enviromental ppn restrictions, https://www. google.hr/url? sa=t\&rct=j\&q=\&esrc=s\&source=web\&cd=1\&ved=0ahUKEwjbh 8 jlInMAhUDkywKHU4oA8cQFggdMAA\&url=https\%3A\%2F\%2Facademiccommons. c o $1 \mathrm{u} \mathrm{m} \mathrm{b}$ i a. e d u \% $2 \mathrm{~F}$ d o w n 1 o a d \% $2 \mathrm{~F} \mathrm{f} \mathrm{e} \mathrm{d} \mathrm{o} \mathrm{r} \mathrm{a}$ content $\% 2$ Fdownload\%2Fac\%3A187221\%2FCONTENT\%2Fganley_eu_product_ procurement.pdf\&usg=AFQjCNF7yUe7D74YNReQIdjok80ptoBjyg\&sig2=vVcf6aP_ PHESINQYEQzDXg, pristupljeno 20. prosinca 2016.

13. Graells, A. S., Public procurement and the EU competition rules, Hart Publishing, 2015.

14. Kingston, S., The uneasy relationship between EU environmental and economic policies, Sustainable procurement under EU law, Cambridge University Press, 2016.

15. McCrudden, C., Legal aspects of sustainable public procurement, https://www.google.hr/ url? sa $=\mathrm{t} \& \mathrm{rct}=\mathrm{j} \& \mathrm{q}=\&$ esrc $=\mathrm{s} \&$ source $=$ web $\& \mathrm{~cd}=1 \& \mathrm{ved}=0 \mathrm{ahUKEwjF} 1 \mathrm{dih} 7 \mathrm{OLJAhXDE}$ HIKHbADDzsQFggiMAA\&url=http $\% 3 \mathrm{~A} \% 2 \mathrm{~F} \% 2 \mathrm{Fmasterpublicprocurement.itcilo.org}$ $\% 2$ Fprivate-area $\% 2$ Flibrary $\% 2$ Fdocuments $\% 2$ Flegal-aspects-of-sustainable-publicprocurement\%2Fat_download\%2FAttachmentFile\&usg=AFQjCNHAiqBhg2-JlvDXC2KfR0uFZL-SQ\&sig2=CIF7h0xZSX68FAS2TiPx9A, pristupljeno 17. prosinca 2015.

16. McCrudden, C., Using public procurement to actieve social outcomes, Natural Resources Forum, vol. 28, br. 4, 2004.

17. Poll, E., Ville, S., Social innovation: Buzz word or enduring term?, Journal of Socio-Economics, 38 (6), http://ro.uow.edu.au/cgi/viewcontent. cgi? article $=1699 \&$ context $=$ commpapers, pristupljeno 7. prosinca 2016.

18. Poulsen, S. T., Jakobsen, P. S., Kalsmose-Hjelmborg S. E., EU public procurement law, DJOF Publishing, 2012.

19. Semple, A., Reform of the EU procurement Directives and WTO GPA: forward steps for sustainability?, http://papers.ssrn.com/sol3/papers.cfm?abstract_id=2089357, pristupljeno 20. prosinca 2016.

20. Semple, A., The Link to the Subject-Matter: A Glass Ceiling for Sustainable Public Contracts?, u Sustainable public procurement under EU law: New perspectives on the state as stakeholder, Cambridge University Press, Cambridge, 2015.

21. Sjafjell B., Wiesbrock A., Why should public procurement be about sustainability, Sustainable procurement under EU law, Cambridge University Press 2016.

22. Thai, K. V., Public procurement re-examined, Journal of public procurement, vol. 1, br. $1,2001$.

23. Wiesbrock, A., Socially responsible public procurement, European value or national choice?, Sustainable public procurement under EU law, Cambridge University Press, 2016.

24. Worthington, I., Ram, M., Shah, M., Boyal, H., Drivers of and barriers to supplier diversity initiatives: a cross-national study, http://www.crrconference.org/Previous conferences/downloads/worthington.pdf, pristupljeno 5. prosinca 2016.

Ostala literatura

1. Zakon o javnoj nabavi, NN br. 90/11, 83/13, 143/13, 13/14

2. Zakon o javnoj nabavi, NN br. 120/16 
3. Direktiva 2009/33/EC Europskog parlamenta i Vijeća od 23. travnja 2009. o poticanju čistih i energetski učinkovitih cestovnih vozila.

4. Direktiva 2014/24/EU Europskog parlamenta i Vijeća od 26. veljače 2014. o javnoj nabavi i o stavljanju izvan snage Direktive 2004/18/EZ

5. Direktiva 2014/25/EU Europskog parlamenta i Vijeća od 26. veljače 2014. o nabavi subjekata koji djeluju u sektoru vodnog gospodarstva, energetskom i prometnom sektoru te sektoru poštanskih usluga i stavljanju izvan snage Direktive 2004/17/EZ

6. Direktiva 2014/23/EU Europskog parlamenta i Vijeća od 26. veljače 2014. o dodjeli ugovora o koncesiji

7. Direktiva Europskog parlamenta i Vijeća 2004/17/EZ od 31. ožujka 2004. o usklađivanju postupaka nabave subjekata koji djeluju u sektoru vodnog gospodarstva, energetskom i prometnom sektoru te sektoru poštanskih usluga

8. Direktiva Europskog parlamenta i Vijeća 2004/18/EZ od 31. ožujka 2004. o usklađivanju postupaka za sklapanje ugovora o javnim radovima, ugovora o javnoj nabavi robe te ugovora o javnim uslugama o dodjeli ugovora o koncesiji

9. Uredba (EC) br. 106/2008 o zajedničkom programu oznaka o energetskoj učinkovitosti za uredsku opremu

10. C-225/98 Komisija protiv Francuske (2000) ECR I-7445.

11. C-31/87 Gebroeders Bentjees BV protiv Nizozemske (1988) ECR 4635.

12. C-368/10, Komisija protiv Nizozemske (2012).

13. C-448/01 EVN $i$ Wienstrom (2003) ECR I-14527.

14. C-513/99 Concordia Bus (2002) ECR I-7213.

15. Novinski izvještaj Europske komisije, http://europa.eu/rapid/press-release_MEMO-1418 en.htm?locale=en, pristupljeno 15. prosinca 2015.

16. Max Havelaar web stranice, http://maxhavelaar.nl/english, pristupljeno 2. prosinca 2016.

17. Nacionalni akcijski plan za zelenu javnu nabavu, http://mzoip.hr/doc/nacionalni akcijski_plan_za_zelenu_javnu_nabavu.pdf, pristupljeno 24. prosinca 2015.

18. Procurement Strategy for Aboriginal Business, http://www.aadnc-aandc.gc.ca/eng/11001 00032802/1100100032803, pristupljeno 5. prosinca 2016.

19. Australian and New Zealand Government Framework for Sustainable Procurement, http://www.apcc.gov.au/ALLAPCC/APCC\%20PUB_ANZ\%20Government\%20 Framework\%20for\%20Sustainable\%20Procurement $\% 20-\% 20$ Sept $\% 202007$.pdf, pristupljeno 5. prosinca 2016.

20. Fairtrade web stranica, http://www.fairtrade.net/about-fairtrade/what-is-fairtrade.html, prostupljeno 2. prosince 2016.

21. Statističko izvješće o javnoj nabavi u Republici Hrvatskoj za 2013. godinu Uprave za sustav javne nabave ministarstva gospodarstva, http://www.javnanabava.hr/ userdocsimages/userfiles/file/Statisti $\%$ C4\%8Dka\%20izvje $\%$ C5 $\%$ A $1 \%$ C4\%87a/ Godi\%C5\%A1nja/Statisticko_izvjesce_JN-2013.pdf, str. 10., pristupljeno 15. prosinca 2015 .

22. Odgovor Ministarstva na zahtjev radi ostvarivanja prava na pristup informacijama, KLASA: 008-01/16-01/198, URBROJ: 517-01-16-4, od 19. prosinca 2016. 


\section{Summary}

\section{SUSTAINABLE PUBLIC PROCUREMENT}

Sustainable public procurement, although a relatively old legal concept, began to take shape significantly in the last 20 years. Large purchasing power of the state and the importance of public procurement procedures for each market necessarily led to the awareness and use of public procurement to achieve the secondary, social and environmental objectives. As such, sustainable public procurement certainly has more advantages than disadvantages. Indirect use of public procurement as a tool in achieving better environmental protection and greater inclusion of socially disadvantaged groups in society must be supported. However, the achievement of those goals must always be secondary, because the main objective of public procurement must be the procurement of the best goods, services or works with the least possible cost to the state budget. Sustainable public procurement has a growing importance in the EU legal order, and thus consequently increasing importance in the legal order of the Republic of Croatia. Beginning with the 2004 EU regulatory framework elements of sustainable procurement are included in the legal systems of all member states, while these elements are significantly more present in the 2014 EU regulatory framework. Certain sustainable elements are significantly expanded, while adding some new. The biggest changes are present in the technical specifications, criteria for selection of offers, conditions for performance of the contract, in the new institute of life cycle costing as well as environmental labels. The biggest problem is the fact that the implementation of sustainable elements in public procurement procedures is still voluntary and there is no way to force the implementation of these elements. However, I still think that the significantly expanded elements of sustainable procurement in the 2014 EU regulatory framework willl certainly have a significant impact on the achievement of the objective of $50 \%$ green public procurement by 2020 . The new provisions in conjunction with the planned promotional activities and education of employees can have a significant impact on raising awareness of the importance of sustainable public procurement. However, the fact that part of sustainable procurement relating to the achievement of social goals is not similarly recognized as important in Croatia is dissapointing.

Keywords: administrative law, public procurement, sustainable development, European union.

\section{Zusammenfassung}

\section{NACHHALTIGE ÖFFENTLICHE BESCHAFFUNG}

In der Arbeit werden das Konzept der nachhaltigen Beschaffung, deren theoretischer Hintergrund und die Entwicklung der Umsetzung in ausländischen 
Rechtssystemen und dem EU- und kroatischen Recht analysiert. Nach der Einführung des theoretischen Rahmens und der Anerkennung, dass es notwendig ist, die Ziele der nachhaltigen Entwicklung im öffentlichen Rechtsrahmen zu fordern, wird die Entwicklung des Konzepts in ausländischen Rechtssystemen beschrieben. Danach wird die allmähliche Entwicklung von Elementen der Nachhaltigkeit in der öffentlichen Beschaffung im EU-Recht durch die Praxis des Europäischen Gerichtshofs und die letzten beiden Rechtsrahmen des öffentlichen Rechts dargestellt.

Im zweiten Teil wird das aktuelle Rechtssystem des öffentlichen Beschaffungswesens in der Republik Kroatien analysiert mit dem Ziel der Erleuchtung der existierenden Elemente einer nachhaltigen Entwicklung sowie der Praxis der inländischen Besteller bei der Umsetzung von Elementen der Nachhaltigkeit im öffentlichen Vergabeverfahren. Die Arbeit schließt mit der Analyse der Auswirken, welche die Ausweitung des Konzepts der nachhaltigen Beschaffung in den neuen Rechtsrahmen der Europäischen Union auf das kroatische Rechtssystem haben wird.

Schlüsselwörter: Verwaltungsrecht, öffentliche Beschaffung, nachhaltige Entwicklung, Europäische Union.

\section{Riassunto}

\section{APPALTO PUBBLICO SOSTENIBILE}

Nel lavoro si analizza il concetto di appalto pubblico sostenibile, come pure il suo fondamento teorico, lo sviluppo della sua attuazione nei sistemi giuridici stranieri, il diritto dell'Unione europea ed il diritto croato. Dopo avere posto in apertura il quadro teorico e dopo avere riconosciuto le esigenze di introduzione di finalità di sviluppo sostenibile nel quadro giuridico degli appalti pubblici, si descrive lo sviluppo di tale concetto nei sistemi giuridici stranieri. Dopo di ciò si illustra lo sviluppo graduale degli elementi di sostenibilità nell'appalto pubblico dell'Unione europea, mediante la giurisprudenza della Corte di Giustizia dell'Unione europea e i due quadri regolatori degli appalti pubblici più recenti. Nella parte seguente del lavoro si analizza il sistema giuridico attuale dell'appalto pubblico nella Repubblica di Croazia con l'intento di accertare l'esistenza di elementi di sviluppo sostenibile, come anche la prassi dei committenti domestici nell'attuazione degli elementi di sostenibilità nella gara dell'appalto pubblico. Il lavoro si conclude con l'analisi circa le modalità con le quali il sistema giuridico influirà sulla diffusione significativa del concetto di appalto pubblico sostenibile nel nuovo quadro di regolamentazione dell'Unione europea.

Parole chiave: diritto amministrativo, appalto pubblico, sviluppo sostenibile, Unione europea. 